\title{
Equal Standing with States: Tribal Sovereignty and Standing after Massachusetts v. EPA
}

Joseph Mead

Cleveland State University, j.mead@csuohio.edu

Nicholas Fromherz

Follow this and additional works at: https://engagedscholarship.csuohio.edu/urban_facpub

Part of the Environmental Law Commons, Indigenous, Indian, and Aboriginal Law Commons, Land Use Law Commons, Natural Resources Law Commons, Property Law and Real Estate Commons, Supreme Court of the United States Commons, Urban Studies and Planning Commons, and the Water Law Commons

How does access to this work benefit you? Let us know!

\section{Repository Citation}

Mead, Joseph and Fromherz, Nicholas, "Equal Standing with States: Tribal Sovereignty and Standing after Massachusetts v. EPA" (2010). All Maxine Goodman Levin School of Urban Affairs Publications. 0123 1449.

https://engagedscholarship.csuohio.edu/urban_facpub/1449

This Article is brought to you for free and open access by the Maxine Goodman Levin School of Urban Affairs at EngagedScholarship@CSU. It has been accepted for inclusion in All Maxine Goodman Levin School of Urban Affairs Publications by an authorized administrator of EngagedScholarship@CSU. For more information, please contact library.es@csuohio.edu. 


\title{
Equal Standing with States:
}

\section{Tribal Sovereignty and Standing After Massachusetts v. EPA}

\author{
Nicholas A. Fromherz
}

Joseph W. Mead

INTRODUCTION

I. MASSACHUSETTS V. EPA.

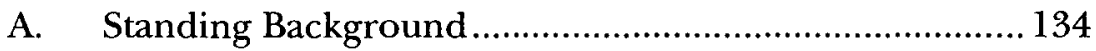

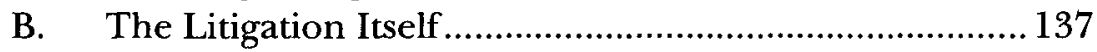

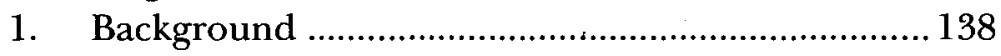

2. Supreme Court ......................................................... 139

C. Sovereignty and Standing after Massachusetts............... 146

II. INDIAN SOVEREIGNTY: ITS NATURE AND SCOPE .........................149

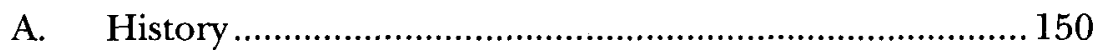

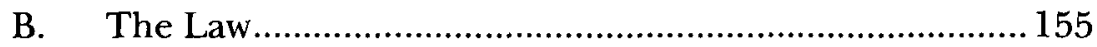

1. The Marshall Trilogy ……......................................... 155

2. Beyond the Marshall Trilogy: Acknowledging

Differences Between Tribal and State Sovereignty . 158

III. CONNECTING THE DOTS.

A. Tribes Are Nevertheless Sovereign .................................. 165

B. Equal Standing With States ............................................170

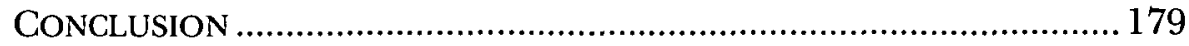

\section{INTRODUCTION}

Over the past century, glaciers around the world have retreated 
at alarming rates; the sea level has risen by half a foot or more; and as many as 2,000,000 species have passed into extinction. ${ }^{1}$ Many have dubbed climate change and environmental degradation the great crises of our time; with this evidence in tow, it is hard to argue otherwise. Small wonder, then, that environmental litigation has attracted enormous attention and support as we make our way into the twenty-first century. But as students of environmental law know, a case with great merit may never get past the preliminary stages. Standing has been the bane of environmental lawyers for decades, because the harms they seek to vindicate do not always pass the rigid test that is more suited to traditional causes-actions with injuries personal and identifiable, like tort and contract. With the Supreme Court's decision in Massachusetts v. EPA, however, standing became just a little less intimidating-at least for sovereign entities. ${ }^{2}$ The Supreme Court held that Massachusetts was entitled to "special solicitude" in the standing analysis because it was sovereign, and therefore it passed the standing threshold in a global warming case where an ordinary litigant may have been stymied. The Supreme Court's analysis raises an interesting question: Are Indian tribes-which have been considered sovereign entities since before the. Founding, and hold lands facing heavy environmental pressure-entitled to "special solicitude" as well? We think they should be, particularly when litigating environmental cases. And lest anyone think this issue merely academic, the Federal Circuit just faced (but did not decide) this very question. ${ }^{3}$

Before we outline our argument, it is important to establish our basic understanding of the term "sovereignty." We will discuss the meaning of this word throughout the paper, but the core idea is this: to be a sovereign entity is to be a politically legitimate group of landed people that is sufficiently autonomous to run its internal affairs and to interact with other sovereigns. ${ }^{4}$ Whether tribes can

1. Tim Green, The Thing About Extinction, http://www.bbc.co.uk/lastchancetosee/ sites/about/extinction.shtml (last visited Jan. 26, 2009).

2. Massachusetts v. EPA, 549 U.S. 497 (2007).

3. Canadian Lumber Trade Alliance v. United States, 517 F.3d 1319, 1337 (Fed. Cir. 2008) ("Analogizing itself to Native American tribes . . Canada argues that it has standing because it is a sovereign seeking to protect its sovereign interests. But to the extent that Native American tribes are entitled to any 'special solicitude' regarding standing . . . Canada has not established that it is similarly situated." (citations omitted))

4. Diane M. Ring, What's at Stake in the Sovereignty Debate?: International Tax and the Nation-State, 49 VA. J. INT'L L. 155, 159-60 (2008). Although the meaning of "sovereignty" 
lay claim to sovereignty as strongly as states for purposes of standing-and, if so, what the upshot should be-are questions that form the heart of this paper. ${ }^{5}$

has "changed over the centuries and across contexts," certain "core elements" have remained constant:

At a minimum, a sovereign state is expected to have three elements: "territory, people, and a government." A sovereign state must have de facto supremacy and control (at least in some measure) over its territory and people (the internal component). That is, the state represents the supreme source of authority on internal matters. Additionally, a state must exhibit some de facto external independence; "not the supremacy of one state over others but the independence of one state from its peers." Id. at 160 (footnotes omitted); see also Leo Gross, The Peace of Westphalia, 1648-1948, 42 AM. J. INT'L L. 20, 20 (1948) (discussing the origins of modern sovereignty). However, "there is no expectation that to claim sovereignty a state must demonstrate complete satisfaction of all of the underlying elements." Ring, supra, at 161.

5. Another term that is critical to our discussion is, of course, "Indians." When Christopher Columbus made landfall on the island of San Salvador in 1492, he called the people he encountered Indians, a common European term for inhabitants of the Far East.

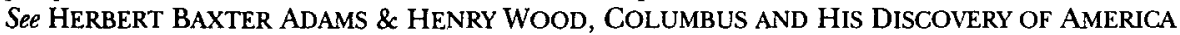
25 (1892); THE JOURNAL OF CHRISTOPHER COLUMBUS 27 (Cecil Jane trans., 1960) (1492); S. James Anaya, Indian Givers: What Indigenous People Have Contributed to International Human Rights Law, 22 WASH. U. J. L. \& POL'Y 107, 107 (2006). Even though Columbus was off by some 9,000 miles, the name stuck. The term Native American came en vogue in some circles during the 1960s and 1970s. Terence Dougherty, Group Rights to Cultural Survival: Intellectual Property Rights in Native American Cultural Symbols, 29 COLUM. HUM. RTS. L. REV. 355, 355 n.1 (1998); Whitney Kerr, Giving UP The "I": How the National Museum of the American Indian Appropriated Tribal Voices, 29 AM. INDIAN L. REV. 421, 428-29 (2004); Yair Listoken, Confronting the Barriers to Native American Homeownership on Tribal Lands: The Case of the Navajo Partnership for Housing, 33 URB. LAw. 433, 433 n.3 (2001). However, our research shows that the indigenous peoples of this country tend to prefer the traditional moniker. David H. Getches, Charles F. Wilkinson, \& Robert A. Williams, Cases and MATERIals on Federal Indian LAW 9 (5th ed. 2005). See also Robert B. Porter, The Meaning of Indigenous Nation Sovereignty, 34 ARIZ. ST. L.J. 75, $75 \mathrm{n} .1$ (2002) ("While it has become increasingly popular within American society and in some corners of Indian country to refer to Indians as 'Native Americans,' this term still seems less utilized among Indians than the term 'Indian.' Moreover, use of the term 'Native American' suggests acceptance of an unsavory assimilationist connotation."). We abide by that preference in this article.

It must also be noted at the outset that when we speak of things Indian in this paper, we speak necessarily in general terms. There are over 300 federally recognized Indian tribes in the contiguous United States, each with a unique history, culture, and associated land. JAKE PAGE, IN THE HANDS OF THE GREAT SPIRIT: THE 20,000-YeAR HISTORY OF AMERICAN INDIANS 2 (2003). It is regrettable to lump these distinct groups into one large (and often vague) category - American Indians - but the confines of this paper require as much. See GETCHES, WILKINSON, \& WILlIAMS, supra, at 9 ("Scholars have observed that 'American Indians typically think of themselves as members of a particular tribe first and as Indians second.'" (footnote omitted)) When we speak of Indians, then, we mean all federally recognized tribes in the continental United States. This excludes unrecognized tribes, which lack official sovereignty. We also exclude native Hawaiians and Alaskans. The law concerning indigenous Hawaiians and Alaskans is unique: the landscape for native Alaskans was changed dramatically with the Alaska Native Claims Settlement Act of 1971, 
To answer those questions, we devote Part I to discussing standing basics, dissecting Massachusetts v. EPA, and making conclusions about the case's driving principles. We conclude that one of the main reasons states get special solicitude is because they have, through federal preemption, lost much of their regulatory power. In Part II we discuss the nature and scope of Indian sovereignty, canvassing the historical and legal narrative and where things stand today. We also note some of the key similarities and points of distinction between tribal and state sovereignty. From there, we put it all together in Part III, arguing that tribes (as sovereign entities) should enjoy the same special solicitude given to states in the standing context, particularly in environmental cases. We contend that tribes are on the whole better positioned to advocate for environmental causes, making the case all the stronger for enhanced tribal standing.

\section{MASSACHUSETTS V. EPA}

Standing has always played a key role in environmental litigation, usually to the chagrin of conservationists. ${ }^{6}$ But in 2007, the Supreme Court altered the law of standing significantly with its decision in Massachusetts v. EPA. The Court effectively lowered the burden on certain types of environmental advocates-sovereign plaintiffs.

43 U.S.C. $\S \S 1601-28$ (Westlaw 2009); see also Jacob T. Levy, Three Perversities of Indian Law, 12 TEX. REV. OF L. \& POL. 329, 332 n.9 (2008), and the government has almost completely ignored the rights of native Hawaiians (at present, they lack federal recognition). See Rice v. Cayetano 528 U.S. 495,519 (2000) (saying it would be a "substantial step" to "find[] authority in Congress . . . to treat Hawaiians or native Hawaiians as tribes," and declining to do so); John M. Van Dyke, The Political Status of the Native Hawaiian People, 17 YALE L. \& POL'Y REv. 95, 97-98 (1998) ("The Native Hawaiians belong to the only native group in the United States that has never been allowed to utilize a claims commission or other mechanism to seek redress for its losses from the federal government."). The ideas in this paper may well apply to these peoples, but we will not test the reader's patience by delving into the nuance.

6. Joshua J. Bruckerhoff, Giving Nature Constitutional Protection: A Less Anthropocentric Interpretation of Environmental Rights, 86 TEX. L. REV. 615, 628 (2008); Robert Stepans, A Case for Rancher-Environmentalist Coalitions in Coal Bed Methane Litigation: Preservation of Unique Values in an Evolving Landscape, 8 WYO. L. REV. 449, 476 (2008). See generally Bradford C. Mank, Standing and Global Warming: Is Injury to All Injury to None?, 35 ENVTL. L. 1 (2005). 


\section{A. Standing Background}

The text of the Constitution limits federal courts" to "cases" and "controversies." divined a number of doctrines to determine whether litigants have brought a case appropriate for judicial resolution. ${ }^{9}$ The Court has announced a formal three-part test for constitutional standing, ${ }^{10}$ a presumption against standing for regulatory beneficiaries, and hostility towards generalized grievances-all of which have posed fatal obstacles to plaintiffs seeking to redress environmental harms. As will be seen below, in Massachusetts v. EPA the Supreme Court defined these rules in such a way that a sovereign may invoke the federal judiciary's power when a non-sovereign litigant may not.

Standing doctrine is typically justified by two theoretical pillars: finding a case that fits within a form that matches the traditional idea of a case $^{11}$ and ensuring presentation of the action in a properly adversarial manner. ${ }^{12}$ The Court has solidified a familiar three-part criteria for standing: (1) a concrete and imminent injury (2) caused by the challenged action that would (3) likely be

7. This section does not address standing to proceed in state courts, which are not bound by limits placed by the Constitution on Article III courts. See generally Note, "Trickle Down" Constitutional Interpretation: Should Federal Limits on Legislative Conferral of Standing be Imported into State Constitutional Law?, 108 COLUM. L. REv. 839 (2008). Nevertheless, many states have adopted the federal standing test. See id. at 855 n.100; Sierra Club v. Haw. Tourism Auth. ex rel. Bd. of Dirs., 59 P.3d 877, 886 (Haw. 2002). Moreover, resort to state court is an unsatisfying answer, as some challenges may only be brought in federal court. For example, the agency denial challenged in Massachusetts can only be brought in a particular federal court-United States Court of Appeals for the District of Columbia. 42 U.S.C. $\S 7607$ (b) (1) (Westlaw 2009). Similarly, challenges to agency action under the Administrative Procedures Act may only be brought in federal court. 5 U.S.C. $§ 702$; Fed. Nat. Mortg. Ass'n v. LeCrone, 868 F.2d 190, 193 (6th Cir. 1989); Double LL Contractors v. State ex rel. Okla. Dept. of Transp., 918 P.2d 34, 42 (Okla. 1996).

8. U.S. Const. art. III.

9. Among these principles are that Courts will not decide a "political question," issue an advisory opinion, or continue with a case after the issue has been mooted by later developments. Flast v. Cohen, 392 U.S. 83, 95 (1968).

10. There is also a line of jurisprudence that establishes prudential, rather than Constitutional, limits on standing. Thus, a plaintiff must generally assert his own rights, and not those of another individual. Kowalski v. Tesmer, 543 U.S. 125, 130 (2004). A plaintiff who asserts only a "generalized grievance" faces dismissal on prudential standing grounds, although this also has been treated by the Court as a Constitutional requirement, as discussed later. A third type of prudential standing limitation is that the plaintiff should assert a claim within the "zone of interest protected by the law invoked." Allen v. Wright, 468 U.S. 737, 751 (1984).

11. Flast, 392 U.S. at 95 (noting that standing limits the Court to cases fitting "a form historically viewed as capable of resolution through the judicial process").

12. Id. (noting the importance of presenting issues "in an adversary context"). 
redressed by a favorable decision. ${ }^{13}$ Proponents of strict limits on standing argue that such limits buttress notions of separation of powers. $^{14}$ Critics complain that the test undervalues injuries, is overly formal, and lacks support from history or the Constitution's text. ${ }^{15}$ Although the details of the standing test, and the extent to which Congress may alter the analysis, have varied as the Court has been confronted with different factual scenarios, this basic test has consistently provided the framework for standing for decades. ${ }^{16}$

The Court has also articulated a separate presumption against standing for individuals who are not the object of the regulation (or lack thereof) they seek to challenge. The Defenders of Wildlife Court stated:

[T]o establish standing depends considerably upon whether the plaintiff is himself an object of the action (or forgone action) at issue. If he is, there is ordinarily little question that the action or inaction has caused him injury, and that a judgment preventing or requiring the action will redress it. When, however, as in this case, a plaintiff's asserted injury arises from the government's allegedly unlawful regulation (or lack of regulation) of someone else, much more is needed. ${ }^{17}$

The consequence of the Court's tripartite approach is the creation of a bias against those who would challenge underprotection of the environment. Regulations may be challenged by regulated industry, but the failure to regulate may go unchallenged for want of an adequate plaintiff. Accordingly, "[t]he net effect of judicial review of administrative action is highly antiregulatory." 18

13. Lujan v. Defenders of Wildlife, 504 U.S. 555, 560-61 (1992).

14. Antonin Scalia, The Doctrine of Standing as an Essential Element of the Separation of Powers, 17 SUFFOLK U. L. REV. 881, 895 (1983).

15. See Eugene Kontorovich, What Standing is Good For, 93 VA. L. REv. 1663, 1665 (2007) ("Scholars almost unanimously regard it as pointless and incoherent at best, a veil for ideological manipulations at worst." (footnotes omitted)). See generally Cass Sunstein, Standing for Animals (with Notes on Animal Rights), 47 UCLA L. REv. 1333, (2000).

16. See Warth v. Seldin, 422 U.S. 490 (1975).

17. Defenders of Wildlife, 504 U.S. at 561-62; see also Scalia, supra note 14, at 894 ("Thus, when an individual who is the very object of a law's requirement or prohibition seeks to challenge it, he always has standing. That is the classic case of the law bearing down upon the individual himself. ...").

18. Frank B. Cross, Shattering the Fragile Case for Judicial Review of Rulemaking, 85 VA. L. 
Obviously, then, standing has posed problems for plaintiffs seeking to litigate environmental claims. Plaintiffs in environmental suits arguably have fared the worst under the modern standing doctrine, ${ }^{19}$ and it is no coincidence that a number of the Supreme Court's pronouncements curtailing standing have been in environmental cases. ${ }^{20}$ The Court has suggested that the federal courts exist "solely[] to decide on the rights of individuals." 21 Environmental harms may fall most directly on animals, plants, and ecosystems, while the harms to individual humans are often too diffuse or attenuated to support standing under the three-part test. ${ }^{22}$

Prior to 2007, as a result, standing for plaintiffs who sought to litigate global warming issues seemed doubtful. Despite the harms that were being suffered, ${ }^{23}$ cases and commentary noted the

REV. 1243, 1322 (1999).

19. Jamie Gibbs Pleune, Is Scalian Standing the Latest Sighting of the Lochner-ess Monster?: Using Global Warming to Explore the Myth of the Corporate Person, 38 ENVTL. L. 273, 281 (2008) ("Environmental injuries do not fare well under Scalian Standing."); see also Defenders of Wildlife, 504 U.S. at 606 (Blackmun, J., dissenting) ("I cannot join the Court on what amounts to a slash-and-burn expedition through the law of environmental standing.").

20. See, e.g., Summers v. Earth Island Inst., 129 S. Ct. 1142, 1149 (2009); Steel Co. v. Citizens for a Better Env't, 523 U.S. 83 (1998); Defenders of Wildlife, 504 U.S. 555; Lujan v. Nat'l Wildlife Fed'n, 497 U.S. 871 (1990); Sierra Club v. Morton, 405 U.S. 727 (1972); see also RICHARD J. LAZARUS, THE MAKING OF ENVIRONMENTAL LAW 134 (2004) ("The Court repeatedly ruled against the citizen's ability to maintain environmental protection. . ..").

21. Defenders of Wildlife, 504 U.S. at 576 (quoting Marbury v. Madison, 5 U.S. (1 Cranch) 137,170 (1803)); see also Friends of the Earth, Inc. v. Laidlaw Envtl. Services, 528 U.S. 167, 181 (2000) ("The relevant showing for purposes of Article III standing, however, is not injury to the environment but injury to the plaintiff.").

22. As a result, some scholars have suggested bestowing standing on natural objects. Christopher Stone, Should Trees Have Standing? Toward Legal Rights for Natural Objects, 45 S. CAL. L. REv. 450, 464-73 (1972); Sunstein, supra note 15, at 1336; Katherine A. Burke, Comment, Can We Stand for It? Amending the Endangered Species Act with an Animal-Suit Provision, 75 U. COLO. L. REV. 633 (2004); Adam Kolber, Note, Standing Upright: The Moral and Legal Standing of Humans and Other Apes, 54 STAN. L. REV. 163 (2001). Indeed, some cases have treated animals as if they had standing to sue. See Burke, supra, at $363 \mathrm{n} .26$; Sunstein, supra note 15, at $1359 \mathrm{nn} .141-42$.

23. By 2002, the World Health Organization had concluded that climate change causes 150,000 deaths per year. WORLD HEALTH ORGANIZATION, WORLD HEALTH REPORT 2002 at 72, available at http://www.who.int/whr/2002/en/. Closer to home, "North America has experienced locally severe economic damage, plus substantial ecosystem, social and cultural disruption from recent weather-related extremes, including hurricanes, other severe storms, floods, droughts, heat waves, and wildfires." INTERGOVERNMENTAL Panel ON Climate Change, NORTH America. Climate Change 2007: ImPaCts, ADAPTATION AND VULNERABILITY 619 (2007), available at http://www.ipcc.ch/pdf/assessment-report/ar4/wg2/ar4-wg2-chapter14.pdf; Mini Kaur, Note, Global Warming Litigation under the Alien Tort Claims Act: What Sosa v. Alvarez Machain 
difficulty of showing injury to a particular plaintiff. ${ }^{24}$ Most people experienced only "minor and general harms from global warming." ${ }^{25}$ And harm that accrued over fifty to one hundred years failed to satisfy the Court's imminence requirement. ${ }^{26}$

There was also a belief that causation and redressability posed insurmountable obstacles to successfully bringing a climate change lawsuit in federal court. ${ }^{27}$ The geographic distance between the greenhouse gas emitter and the environmental harm relied upon by the plaintiff made standing highly questionable. ${ }^{28}$ Proving the link between a specific emitter and a particular harm also stood as a barrier, particularly in light of what had been perceived to be inconclusive evidence. ${ }^{29}$ Before Massachusetts, the justiciability of global warming issues was believed to be unlikely, and then only for a limited breed of cases. ${ }^{30}$

\section{B. The Litigation Itself}

Against this backdrop, the petitioners' cause in Massachusetts $v$. $E P A$ seemed destined for failure. The petitioners claimed that auto emissions were harming the environment, and EPA needed to do something about it. Though they prevailed in the end, the road was long and far from obstacle-free. ${ }^{31}$ It took nearly nine years for the issue to travel from a request for rulemaking by a collection of non-profit organizations to the Supreme Court's edict. EPA originally declined to regulate, and a panel of the D.C. Circuit

and its Progeny Mean for Indigenous Arctic Communities, 13 WASH. \& LEE J. CIVIL RTS. \& SOC. JUST. 155, 181 (2006).

24. Fla. Audubon Soc'y v. Bentsen, 94 F.3d 658, 666 (D.C. Cir. 1996) (en banc) (denying standing in a global warming suit); Christopher L. Muehlberger, Comment, One Man's Conjecture is Another Man's Concrete: Applying the "Injury-in-Fact" Standing Requirement to Global Warming, 76 UMKC L. REv. 177, 195-201 (2007) (citing several examples of injuries caused by climate change).

25. Mank, supra note 6 , at 82 .

26. Blake R. Bertagna, Comment, "Standing" Up For The Environment: The Ability of Plaintiffs to Establish Legal Standing to Redress Injuries Caused by Global Warming, 2006 B.Y.U. L. REv. 415, 468 (2006).

27. Muehlberger, supra note 24, at 185; see also Fla. Audubon Soc'y v. Bentsen, 94 F.3d at 668-72; Bertagna, supra note 26 , at 468 .

28. Bertagna, supra note 26 , at $449-50$.

29. Id. at 468 .

30. See id. at 471 .

31. EPA has reconsidered its position and now is working to regulate greenhouse gases. See Proposed Endangerment and Cause or Contribute Findings for Greenhouse Gases Under Section 202(a) of the Clean Air Act, 74 Fed. Reg. 18,886 (proposed April 24, 2009). 
affirmed the denial in a highly fractured opinion. The Supreme Court reversed, finding that Massachusetts had standing, and the agency erred when it concluded that regulation of greenhouse gases was improper. In so doing, the Court announced a rule of "special solicitude" weighing in favor of state standing in federal court.

\section{Background.}

On October 20, 1999, a number of organizations ${ }^{32}$ petitioned EPA to regulate the emission of carbon dioxide $\left(\mathrm{CO}_{2}\right)$, methane $\left(\mathrm{CH}_{4}\right)$, nitrous oxide $\left(\mathrm{N}_{2} \mathrm{O}\right)$, and hydro fluorocarbons (HFCs) from new motor vehicles under the Clean Air Act. ${ }^{33}$ Fifteen months later, EPA requested public comment on the petition and received nearly 50,000 comments. ${ }^{34}$ EPA concluded that it lacked authority under the Clean Air Act "to address global climate change" by regulating so-called greenhouse gases (GHGs). ${ }^{35}$ In addition to lack of authority, EPA stated that it "would decline the petitioners' request to regulate motor vehicle GHG emissions even if it had authority to promulgate such regulations," emphasizing "scientific uncertainty" and its pursuit of alternate policy approaches. ${ }^{36}$

Twelve states, ${ }^{37}$ the District of Columbia, American Samoa, two cities ${ }^{38}$ and fourteen private organizations ${ }^{39}$ filed a petition for

32. These organizations were the International Center for Technology Assessment, Alliance for Sustainable Communities, Applied Power Technologies, Bio Fuels America, California Solar Energy Industries Association, Clements Environmental Corporation, Environmental Advocates, Environmental and Energy Study Institute, Friends of the Earth, Full Circle Energy Project, Green Party of Rhode Island, Greenpeace USA, Network for Environmental and Economic Responsibility of the United Church of Christ, New Jersey Environmental Watch, New Mexico Solar Energy Association, Oregon Environmental Council, Public Citizen, Solar Energy Industries Association, SUN DAY Campaign. Massachusetts v. EPA, 549 U.S. 497, 510 n. 15 (2007).

33. Control of Emissions from New Highway Vehicles and Engines, 68 Fed. Reg. $52,922,52,922-52,923$ (Sept. 8, 2003) (denial of petition for rulemaking).

34. Id. at 52,924 .

35. Id. Two general counsel opinions had reached a contrary conclusion shortly before the petition was filed. Massachusetts, 549 U.S. at 510-11. 52,931

36. Control of Emissions from New Highway Vehicles and Engines, 68 Fed. Reg.. at

37. These states were California, Connecticut, Illinois, Maine, Massachusetts, New Jersey, New Mexico, New York, Oregon, Rhode Island, Vermont, and Washington. Massachusetts, 549 U.S. at 505 n.2.

38. The two cities were New York City and Baltimore. Id. at 505 n.3.

39. The private organizations were Center for Biological Diversity, Center for Food 
review of EPA's denial of the rulemaking request in the United States Court of Appeals for the District of Columbia. ${ }^{40}$ Six additional states filed an amicus brief at the Supreme Court level supporting the petitioners. ${ }^{41}$ Ten states intervened to support EPA's decision, ${ }^{42}$ and Indiana supported the intervenor states at the D.C. Circuit as an amicus. These latter states argued that- EPA correctly interpreted the statute, and did not argue the standing issue. $^{43}$

\section{Supreme Court.}

Although EPA prevailed in the Court of Appeals-as orthodox standing jurisprudence would have predicted-the Supreme Court reversed. Before it could address the merits, the Court had to find that at least one litigant had standing. ${ }^{44}$ The Court employed a

Safety, Conservation Law Foundation, Environmental Advocates, Environmental Defense, Friends of the Earth, Greenpeace, International Center for Technology Assessment, National Environmental Trust, Natural Resources Defense Council, Sierra Club, Union of Concerned Scientists, and U.S. Public Interest Research Group. Id. at 505 n.4.

40. Challenges to final agency action under the Clean Air Act "may be filed only in the United States Court of Appeals for the District of Columbia." 42 U.S.C. $\$ 7607$ (b) (1) (Westlaw 2009); see also Massachusetts v. EPA, 415 F.3d 50, 53 (D.C. Cir. 2005).

41. Arizona, Iowa, Maryland, Minnesota, and Wisconsin filed one brief, and Delaware filed its own. Brief of Arizona et al. as Amicus Curiae Supporting Petitioners, Massachusetts, 549 U.S. 497 (No. 05-1120), 2006 WL 2563380; Brief of State of Delaware as Amicus Curiae Supporting Petitioners, Massachusetts v. EPA, 549 U.S. 497 (2007) (No. 051120), 2006 WL 2569576.

42. These states were Michigan, Texas, Idaho, North Dakota, Utah, South Dakota, Alaska, Kansas, Nebraska, and Ohio. Brief of Michigan et al., Massachusetts, 549 U.S. 497 (No. 05-1120), 2006 WL 3095443. Idaho chose not to join the intervenors" merits brief in support of the respondent before the Supreme Court. See id.

43. Interestingly, the states that wanted agency action were near the coast, with the exception of Iowa, Minnesota, and Wisconsin, while only Texas and Alaska opposed agency action and had ocean coastline. All states that opposed agency action had voted for the Republican presidential candidate in 1992, 1996, 2000, and 2004, with the exception of Michigan and Ohio - both states with heavy automobile industry. One author observed that states with hydrocarbon-heavy energy use sided with EPA, while those with a relatively low percentage of hydrocarbon energy use sided with the petitioners. Andrew P. Morriss, Litigating to Regulate: Massachusetts v. Environmental Protection Agency, 2007 CATO SUP. CT. REV. 193, 211-12 (2006-07).

44. Massachusetts, 549 U.S. at 518 (citing Rumsfeld v. Forum for Academic and Institutional Rights, Inc., 547 U.S. 47, $52 \mathrm{n} .2$ (2006)). The Court relied on the rule that only one plaintiff/petitioner must have standing to support standing. The full implications of this rule have yet to be explored. On the one hand, the rule "makes sense as a matter of policy" because there are no adverse consequences to the parties of the rule. Joan Steinman, The Effects of Case Consolidation on the Procedural Rights of Litigants: What They Are, What They Might Be; Part 1: Justiciability and Jurisdiction (Original and Appellate), 42 UCLA L. REv. 717, 731 (1995). The costs of defending the suit will likely be constant regardless of 
two-step analysis to find that Massachusetts had standing. First, it noted the status of Massachusetts as a state, rather than an ordinary litigant. ${ }^{45}$ Then, identifying damage to Massachusetts's coastline as the harm, it applied the familiar three-part inquiry into injury, causation, and redressability. ${ }^{46}$ Chief Justice Roberts authored a dissent disputing both points. ${ }^{47}$

With respect to the first point, the Court afforded the state plaintiffs "special solicitude in [the] standing analysis" employed the three-part test-an act, complained the dissent, that "change[d] the rules." ${ }^{\text {A9 }}$ A state is not like an ordinary litigant, the majority reasoned, because it has surrendered three "sovereign prerogatives" to the federal government: 1) the right to invade neighboring territory to prevent harm to its land $;^{50} 2$ ) the right to negotiate treaties with foreign nations; ${ }^{51}$ and 3 ) the right to exercise its police power absent preemption from a higher sovereign.$^{52}$

Additionally, the Court relied on language from a case from 1907 brought up by Justice Kennedy during oral argument to support this "special solicitude," $" 53$ and noted that Massachusetts sought to "protect[] its quasi-sovereign interests." ${ }^{54}$ A quasisovereign interest is distinguishable from a sovereign interest, a proprietary interest, and a private interest of a state citizen. ${ }^{5.5} \mathrm{~A}$

the number of plaintiffs, while the plaintiffs will be bound by res judicata and benefit from a positive ruling. See id. Once a plaintiff establishes standing, the Court has jurisdiction because it is presented with a case or controversy with adversarial presentation. Moreover, the rule comports with the authority courts bestow on individuals to intervene or file amicus briefs to fully vet the issues, even absent usual Article III standing. Yet there could be problems if a court fails to clearly delineate between those plaintiffs with standing and those without in some circumstances, particularly where a factual dispute presents itself. This is especially true if we are to take seriously the clarity-of-the-issues rationale offered for standing.

45. Massachusetts, 549 U.S. at 520.

46. See id. at 521-26.

47. Id. at 536-49 (Roberts, C.J., dissenting).

48. Id. at 520 .

49. Id. at 536 (Roberts, C.J., dissenting).

50. Id. at 519 (majority opinion) ("Massachusetts cannot invade Rhode Island to force reductions in greenhouse gas emissions ....").

51. Id. ("[Massachusetts] cannot negotiate an emissions treaty with China or India ....").

52. Id. (" $[\mathrm{I}] \mathrm{n}$ some circumstances the exercise of [Massachusetts'] police powers ... might well be pre-empted.").

53. Id. at 518 (citing Georgia v. Tenn. Copper Co., 206 U.S. 230 (1907)).

54. Id. at 520 .

55. Alfred L. Snapp \& Son, Inc. v. Puerto Rico ex rel. Barez, 458 U.S. 592, 601-02 
sovereign interest is the state's interest in governing. Two examples of this interest are the state's interest in the recognition of its borders and the validity of its legal code. ${ }^{56} \mathrm{~A}$ proprietary interest is the state's interest as a landowner, for example. ${ }^{57}$ When the state pursues the interests of another party "only for the sake of the real party in interest," it is acting only as a nominal party ${ }^{58}$ No sovereign or quasi-sovereign interests are implicated. The essence of a quasi-sovereign interest, on the other hand, is when the state seeks to assert the rights of its citizens as well as its own "interest[] . . . in the well-being of its populace. ${ }^{.59}$ In such a case, the state may proceed parens patriae, an ancient doctrine literally meaning "parent of the country." 60

Having made much of the fact that Massachusetts is a state, the Court nevertheless chose to apply the traditional three-part test without again explicitly referencing the special status of the petitioner. ${ }^{61}$ Indeed, the dissent criticized the rule by stating, "It is not at all clear how the Court's 'special solicitude' for Massachusetts plays out in the standing analysis, except as an implicit concession that petitioners cannot establish standing on traditional terms." ${ }^{62}$ Yet the majority did not address whether Massachusetts could have established standing as a private litigant. Instead, it appears that the Court found that Massachusetts with "special solicitude" had standing, and therefore did not need to address whether it would qualify for standing without a sovereign boost. $^{63}$

Turning to the injury, the Court identified the relevant harm as that to Massachusetts's coastline, and noted that the state was "alleg[ing] a particularized injury in its capacity as a landowner."

(1982) (contrasting the various types of interests).

56. Id. at 601 .

57. Id. at 601-02.

58. Id. at 602 .

59. Id.

60. Sara Zdeb, From Georgia v. Tennessee Copper to Massachusetts v. EPA: Parens Patriae Standing for State Global-Warming Plaintiffs, 96 GEO. L.J. 1059, 1068 (2008).

61. See Massachusetts, 549 U.S. at 521-26.

62. Id. at 540 .

63. See id. at 521 (majority opinion); Bradford Mank, Should States Have Greater Standing Rights than Ordinary Citizens?: Massachusetts v. EPA's New Standing Test for States, 49 WM. \& MARY L. REV. 1701, 1730 (2008) [hereinafter “Mank, Standing”].

64. Massachusetts, 549 U.S. at 522. The Court found that Massachusetts "'owns a substantial portion of the state's coastal property." Id. (quoting Karst Hoogebloom Decl. at If 4, Massachusetts v. EPA, 549 U.S. 497 (2007) (No. 05-1120), 2006 WL 2569818). 
The dissent was quick to observe that this injury as a landowner was a proprietary interest, not a quasi-sovereign one, and provided no support for the Court's "special solicitude" rule. ${ }^{65}$ The uncontested affidavits submitted by Massachusetts asserted that rising sea levels had already begun to decrease its coastline ${ }^{66}$, and this problem would worsen "over the course of the next century." ${ }^{67}$ The dissent argued that Massachusetts's injury was not particularized, in that global warming affects everyone. The state's loss of its coastal land was an injury it possessed uniquely, responded the majority. ${ }^{68}$ Because EPA conceded the link between human-caused greenhouse gases and global warming, the majority assumed the connection between the United States transportation sector and global warming harms. ${ }^{69}$ The Court reasoned that the emissions from the United States play an incremental part in global warming, even if only a small one. ${ }^{70}$ As a corollary, regulating

Actually, during oral argument counsel noted that the state owns two hundred miles of coastline, which turns out to be just over thirteen percent of the state's 1,500 miles of coastline. Transcript of Oral Argument at 15, Massachusetts v. EPA, 549 U.S. 497 (2007) (No. 05-1120), 2006 WL 3431932.

65. Id. at 539 (Roberts, C.J., dissenting); see also Karl S. Coplan, Direct Environmental Standing for Chartered Conservation Corporations, 12 DUKE ENVTL. L. \& POL'Y F. 183,212 (2001).

66. Although the Chief Justice identified a total of forty-three declarations in support of standing, Massachusetts, 549 U.S. at 542, the petitioners relied on two in front of the Supreme Court: the declaration of Michael MacCracken, former senior scientist at the Office of the U. S. Global Change Research Program, and that of Michael Walsh, a mechanical engineer. Both MacCracken and Walsh concluded that regulatory action would cause a reduction in automobile emissions in the United States, and the technology developed would spread to other countries, reducing their emissions as well. McCracken Decl. at II 32, Massachusetts v. EPA, 549 U.S. 497 (2007) (No. 05-1120), 2006 WL 2569818; Walsh Decl. at II 12, Massachusetts v. EPA, 549 U.S. 497 (2007) . (No. 05-1120), 2006 WL 2569818. MacCracken explained that the United States was responsible for approximately twenty-two percent of the world's fossil fuel emissions during the 1990s, with the United States transportation sector accounting for thirty-two percent of that, or approximately seven percent of world-wide emissions. MacCracken Decl. at I 31. As a result of global warming, MacCracken declared, sea levels have risen between four and eight inches during the twentieth century, with a likely additional eight to twenty-eight inch rise by 2100. Id. at II 23.

67. Massachusetts, 549 U.S. at 523.

68. Id. at $522-23$.

69. In what through the lens of hindsight looks like strategic error, the agency chose to accept as true the experts' opinions, arguing that such allegations were insufficient as a matter of law. Nevertheless, the dissent still dismissed the declarations as "pure conjecture," and "conclusory." Id. at 542, 546. Similarly, Judge Randolph at the lower court buttressed his skepticism for the petitioners' claims by noting that the administrative record "contradict[ed]" their assertions and stating that they simply had not proved their allegations. Massachusetts v. EPA, 415 F.3d 50, 55 (D.C. Cir. 2005) (Randolph, J.).

70. Massachusetts, 549 U.S. at 524. 
carbon dioxide emissions would "reduce[] to some extent," perhaps a very small extent, the harm to Massachusetts's coastline. ${ }^{71}$ In the end, then, the test for standing was satisfied with the aid of special solicitude: Massachusetts suffered an injury; the harm was caused by emissions; and EPA regulation would mitigate the harm. ${ }^{72}$

Given the varying rationales employed by the Court, the weight that "special solicitude" plays in the analysis remains unclear. ${ }^{73}$ Some have suggested that Massachusetts would have satisfied the standing test for an ordinary litigant. ${ }^{74}$ Yet by emphasizing Massachusetts' status as a sovereign, the Court chose not to reach that thornier issue, and adopted instead a rule providing states with "special solicitude." ${ }^{\text {. }}$ Lower courts have rested on the sovereignty aspect of the decision, granting special solicitude to sovereigns $^{76}$ and denying it to non-sovereigns. ${ }^{77}$ The clearest lesson-and most dramatic holding-of the decision is that sovereignty matters to the standing analysis in the future.

71. Id. at 526 .

72. The ultimate merits of the standing analysis need not distract us for long, as the decision is the law of the land unless the Supreme Court revisits it; however, it is worth noting that commentators have on balance supported the decision. See Mank, Standing, supra note 63 , at 1785 ; Zdeb, supra note 60 , at 1082. Apart from standing, the other key issue was of course EPA's treatment of greenhouse gasses-the merits of the case. On that score, the Court decided that the Clean Air Act authorizes EPA to regulate greenhouse gases, and the agency erred in declining to regulate them. This conclusion was disputed in a dissent penned by Justice Scalia. This portion of the holding has been debated by other scholars, and is not important for the arguments made in this article.

73. See Jody Freeman \& Adrian Vermeule, Massachusetts v. EPA: From Politics to Expertise, 2007 SUP. CT. REV. 51, 70 ("The multiple bases for standing identified in the Court's opinion produce a great deal of uncertainty. It is not clear which if any components of the Court's standing analysis will generalize beyond this case."); Mank, Standing, supra note 63, at 1746, 1755.

74. Michael Sugar, Massachusetts v. Environmental Protection Agency, 31 HARV. ENVTL. L. REV. 531, 542 (2007) ("[I]t is unclear how "special solicitude" operates in this case because Massachusetts has standing under the Defenders of Wildlife test as traditionally applied."); see also Shi-Ling Hsu, The Identifiability Bias in Environmental Law, 35 FLA. ST. U. L. REv. 433, 468 (2008) ("Would the same result have been obtained for an individual? Or a public interest organization?"),

75. Massachusetts, 549 U.S. at 520.

76. Wyoming ex rel. Crank v. United States, 539 F.3d 1236, 1241 (10th Cir. 2008).

77. Pub. Citizen, Inc. v. Nat'l Highway Traffic Safety Admin., 489 F.3d 1279, 1294 n.2 (D.C. Cir. 2007). One case declined to extend special solicitude to foreign nations, reasoning that a foreign nation's sovereign prerogatives were not lodged in the United States government. Canadian Lumber Trade Alliance v. United States, 517 F.3d 1319, 1337 (Fed. Cir. 2008). That case expressly noted that Indian tribes were distinguishable from foreign nations on that ground. Id. 
Digging deeper, the Court expressly relied on preemptiondisplacement of state law by federal law-and we believe that this, more than any other factor, helps explain the rationale for the decision. The Court identified as a sovereign interest the state's interest in having regulations cover its territory-an interest that is not always protected by today's legal rules. ${ }^{78}$ Congress's authority to legislate under the Commerce Clause is expansive, and delegation of that authority to agencies is almost expected. Preemption clauses are commonplace in statutes, and even in a silent statute "inconsistent" state laws are declared void by the courts. ${ }^{79}$ Even agencies have the authority to preempt state laws. ${ }^{80}$ Moreover, with the passage of the Seventeenth Amendment, ${ }^{81}$ states lost a large part of their political influence over Congress. ${ }^{82}$

In addition to the traditionally understood injuries, courts have recognized that states may suffer an injury in the form of preemption of their laws. ${ }^{83}$ This is generally identified as the relevant injury for purposes of satisfying the three-part standing framework. ${ }^{84}$ This is consistent with the way the Supreme Court has recognized the harm that preemption can cause a state. For

78. Massachusetts v. EPA, 549 U.S. 497,519 (2007). The significance to the special solicitude test of a sovereign interest in avoiding preemption was emphasized in an online companion to the Northwestern University Law Review. Kathryn A. Watts \& Amy J. Wildermuth, Massachusetts v. EPA: Breaking New Cround on Issues Other than Global Warming, 102 NW. U. L. REV. 1, 8-11 (2007)

79. See Buckman Co. v. Plaintiffs' Legal Comm., 531 U.S. 341 (2001); Geier v. Am. Honda Motor Co., 529 U.S. 861,869 (2000).

80. See generally, Nina A. Mendelson, Cherron and Preemption, 102 MICH. L. REv. 737 (2004).

81. "The Senate of the United States shall be composed of two Senators from each state, elected by the people thereof ...." U.S. CONST. amend. XVII.

82. Ralph A. Rossum, The Irony of Constitutional Democracy: Federalism, the Supreme Court, and the Seventeenth Amendment, 36 SAN DIEGO L. REV. 671, 680-87 (1999); Todd J. Zywicki, Beyond the Shell and Husk of History: The History of the Seventeenth Amendment and its Implications for Current Reform Proposals, 45 CLEV. ST. L. REV. 165, 169-75 (1997). Yet one article implies criticism because states have greater legislative input than ordinary citizens because "surely the states can spur legislative oversight of a recalcitrant EPA by enlisting sympathetic members of their congressional delegations to hold hearings or otherwise make life difficult for the agency." Freeman \& Vermeule, supra note 73, at 68.

83. Bowen v. Pub. Agencies Opposed to Soc. Sec. Entrapment, 477 U.S. 41,50 n.17 (1986); Tex. Office of Pub. Utility Counsel v. F.C.C., 183 F.3d 393, 449 (5th Cir. 1999); Ill. Dept. of Transp. v. Hinson, 122 F.3d 370, 372 (7th Cir. 1997); Alaska v. U.S. Dept. of Transp., 868 F.2d 441, 443 (D.C. Cir. 1989); Ohio ex rel. Celebrezze v. U.S. Dept. of Transp., 766 F.2d 228, 232-33 (6th Cir. 1985). But see Amicus Br. of Arizona at *23, Massachusetts v. EPA, 549 U.S. 497 (2007) (No. 05-1120) (stating that the Supreme Court never expressly adopted this theory).

84. Alaska, 868 F.2d 441, 443 (D.C. Cir. 1989). 
example, the Supreme Court has articulated as a sovereign interest the validity of one's legal code ${ }^{85}$ Similarly, the harm visited by preemption has been acknowledged by the Supreme Court with its creation of the "presumption against preemption" doctrine. ${ }^{86}$ Implicitly the Court recognizes that the harm of preemption is so great that statutes will be construed when possible to limit the existence and scope of preemption.

Here, it can be admitted, Massachusetts's injury was not simply preemption. Nor was it simply the loss of coastline. It was both of these harms together that created a cognizable injury. Absent preemption, Massachusetts was free to address any perceived harm through the exercise of its general police power, circumscribed only by limitations imposed by the electorate and the Constitution. With preemption, the concerns of Massachusetts could only be answered by EPA, and Massachusetts's power for resolving the problem was now "lodged in the Federal Government" federal government choosing not to address the problem. Under the special solicitude rule, the types of injury sufficient to permit standing are likely expanded. Environmental harms that were previously dismissed as insufficient or inconclusive, when aggregated with the state's sovereign desire for regulation and the incentives of the Clean Air Act, are now capable of supporting standing.

In the context of environmental regulation, moreover, recognition of preemption is critical. Environmental statutes are particularly susceptible to broad preemption clauses, as such preemption is often needed to satisfy industry and lower costs through national uniformity. ${ }^{88}$ The Clean Air Act in particular. recognizes this compromise, containing a broad preemption clause preventing states from regulating automobile emissions. ${ }^{89}$

85. Alfred L. Snapp \& Son, Inc. v. Puerto Rico ex rel. Barez, 458 U.S. 592, 601 (1982).

86. See, e.g., Bates v. Dow Agrosciences LLC, 544 U.S. 431, 449 (2005); Medtronic, Inc. v. Lohr, 518 U.S. 470, 485 (1996).

87. Massachusetts v. EPA, 549 U.S. 497, 519 (2007).

88. See Jessica L. Powers, Comment, Reduce Reuse, Resort to Litigation: Global Warming Lawsuits and What they Mean for Texas, 40 TEX. TECH L. REV. 123, 147 n.263 (2007).

89. 42 U.S.C. $\$ 7543$ (a) (Westlaw 2009) ("No State or any political subdivision thereof shall adopt or attempt to enforce any standard relating to the control of emissions from new motor vehicles or new motor vehicle engines subject to this part."). In light of the definition of "emission standard" that applies only to the emission of "air pollutants," 42 U.S.C. $\$ 7602(k)$ (Westlaw 2009), states relied on EPA's conclusion that greenhouse gases were not "air pollutants," and therefore argued that their regulations of automobile emissions were not preempted. See Cent. Valley Chrysler-Jeep v. Witherspoon, 456 F. Supp. 


\section{Sovereignty and Standing after Massachusetts}

Under Massachusetts, the sovereignty of the litigant alters the standing test in four notable ways: a) the purposes served by standing predominate over the strictures of the formal test; b) harms to quasi-sovereign interests count as injuries for purposes of standing; c) generalized grievances are more likely to be tolerated when the plaintiff is a sovereign; and d) deference will be given to the sovereign's factual assessments. Each of these alterations proves that sovereignty is critical to the standing analysis. ${ }^{90}$

2d 1160 (E.D. Cal. 2006). This argument is clearly foreclosed by Massachusetts's .holding that greenhouse gases are air pollutants. However, another district court found Vermont's greenhouse gas regulations were not preempted by the Clean Air Act when a waiver has been issued. Green Mountain Chrysler Plymouth Dodge Jeep v. Crombie, 508 F. Supp. 2d 295 (D.Vt. 2007). See generally Kevin O. Leske, A Closer Look at Green Mountain Chrysler v. Crombie, 32 VT. L. REV. 439 (2008). The law permits EPA to grant a waiver of this preemptive section to California and other states that have adopted California's standards, although EPA indicated that it would deny the waiver in 2008 for the first time. See Margot Roosevelt, EPA Justifies Denial of Waiver for Califormia, LA TIMES, Mar. 1, 2008. A state does not have a preemptive injury when their regulations are saved from preemption. See Tex. Office of Pub. Utility Counsel v. F.C.C., 183 F.3d 393, 419 (5th Cir. 1999) (holding that a state cannot assert a sovereign interest as injury when it possesses veto power over federal regulation). Once President Obama took office, however, he ordered EPA to reconsider that decision. Ken Bensinger \& Jim Tankersley, Obama Moves to Force Automakers to Produce More Fuel-efficient Vehicles, LA TIMES, Jan. 27, 2009.

90. Some have emphasized the procedural rights aspect of Massachusetts. La. Envtl. Action Network v. McDaniel, No. 06-4161, 2008 WL 803407, at *3 (E.D.La. Mar. 12, 2008). Yet the case does not fit neatly within the relaxed standing afforded to plaintiffs asserting a procedural right. The paradigmatic procedural injury case is one brought under NEPA challenging the failure to create an Environmental Impact Statement. E.g. Citizens for Better Forestry v. U.S. Dept. of Agric., 341 F.3d 961, 970 (9th Cir. 2003); Comm. to Save the Rio Hondo v. Lucero, 102 F.3d 445, 448 (10th Cir. 1996); Fla. Audubon Soc. v. Bentsen, 94 F.3d 658, 664 (D.C. Cir. 1996) (en banc). See generally Zachary D. Sakas, Footnotes, Forests, And Fallacy: An Examination of the Circuit Split Regarding Standing in Procedural Injury-Based Programmatic Challenges, 13 U. BALT. J. ENVTL. L. 175 (2006). NEPA however, is a law that is vigorously non-substantive. Strycker's Bay Neighborhood Council, Inc. v. Karlen, 444 U.S. 223, 227-28 (1980) (per curiam); Vt. Yankee Nuclear Power Corp. v. NRDC, 435 U.S. 519,558 (1978) (noting that NEPA imposes "essentially procedural" duties). The relaxed standard has occasionally been applied to statutory challenges beyond NEPA when those statutes' procedural requirements can be "likened . . . to those required under NEPA." Randall S. Abate \& Michael J. Myers, Broadening the Scope of Environmental Standing: Procedural and Informational Injury-in-Fact After Lujan v. Defenders of Wildlife, 12 UCLA J. ENVTL. L. \& POL'Y 345, 378 (1994). But it doesn't provide any help if you want to challenge the substance of an agency decision. See, e.g., Nat'l Parks Conservation Ass'n v. Manson, 414 F.3d 1, 5 (D.C. Cir. 2005) (noting that failure to prepare EIS is typical procedural injury and contrasting arbitrary and capricious review with allegations of procedural injury); Kristen M. Shults, Comment, Friends of the Earth v. Laidlaw Environmental Services: A Resounding Victory for Environmentalists, Its Implications on Future Justiciability Decisions, and Resolution of Issues on Remand, 89 GEO. L.J. 1001, 1010 n.56 (2001). Massachusetts was disputing the merits of the agency's decision, seeking 
First, the Supreme Court signaled that the purposes of standing should be salient when considering a sovereign litigant. Although it applied the traditional three-part test, the Supreme Court departed from past practice and focused on whether the goals of standing-ensuring zealous advocacy and a crystallized dispute - would be satisfied by Massachusetts's suit. ${ }^{91}$ The majority emphasized that Massachusetts's dual status as a sovereign and landowner "reinforce[d] the conclusion that its stake in the outcome [wa]s sufficiently concrete to warrant the exercise of federal judicial power," ${ }^{92}$ and concluded that the state would vigorously prosecute its interest. ${ }^{93}$

Additionally, we believe that the presence of a sovereign alters the separation-of-powers calculus that drove the Supreme Court to curtail private litigant standing. A state that commences a lawsuit is more than simply the ideological intermeddler that worries courts. ${ }^{94}$ The concerns prompting the Court to disapprove of ideological plaintiffs, such as the potential for manipulation ${ }^{95}$ and opening the floodgates of litigation, ${ }^{96}$ are simply not present with

substantive review. See Bertagna, supra note 26, at 433 .

91. Massachusetts v. EPA, 549 U.S. 497, 519 (2007). As commentators love to point out, these concerns are conspicuously absent from the formalistic test developed. Jonathan R. Siegel, A Theory of Justiciability, 86 TEX. L. REV. 73, 89 (2007) ("[S]tanding doctrine does not bear any necessary relationship to vigorous advocacy. Nor does it even serve as a suitable, if rough, proxy for the practical likelihood that a plaintiff will do a good job of illuminating issues for the courts....").

92. Massachusetts, 549 U.S. at 519.

93. See id: at 521 .

94. Allen v. Wright, 468 U.S. 737, 756 (1984); Found. on Econ. Trends v. Watkins, 794 F. Supp. 395, 397 (D.D.C. 1992) ("The purpose of [the three-part test] is to ensure that the judicial power exercised by federal judges remains confined to the adjudication of particular 'cases' and 'controversies,' as set forth in Article III, and not extended to the resolution of disputes by litigants with no more than an ideological interest in a problem, no matter how deeply that interest may be held.").

95. See Maxwell L. Stearns, From Lujan to Laidlaw: A Preliminary Model of Environmental Standing, 11 DUKE ENVTL. L. \& POL'Y F. 321, 334 n.34 (2001) ("Absent standing, ideological interest groups could manipulate circuit splits as a means to effectively force the grant of certiorari, rendering docket control illusory.").

96. See Laura L. Little, It's About Time: Unravelling Standing and Equitable Ripeness, 41 BuFf. L. REv. 933, 965 (1993); c.f. Allen, 468 U.S. at 756 (complaining that ideological harm could permit "all members of the particular racial group[]" to sue, including "[a] black person in Hawaii [who] could challenge the grant of a tax exemption to a racially discriminatory school in Maine"); United States v. Richardson, 418 U.S. 166, 192 (1974) (Powell, J., concurring) ("Quite apart from this possibility, we risk a progressive impairment of the effectiveness of the federal courts if their limited resources are diverted increasingly from their historic role to the resolution of public-interest suits brought by litigants who cannot distinguish themselves from all taxpayers or all citizens."). 
challenges like Massachusetts's. Budgetary constraints ${ }^{97}$ and political accountability ${ }^{98}$ protect against intervention based on whimsy or a desire to manipulate. And the courts need not worry about being inundated with lawsuits, as there are relatively few states, and no indication that these states are eager plaintiffs. ${ }^{99}$ States' legendary lack of resources assures courts that the few sovereigns entitled to invoke special solicitude will not frequently or arbitrarily do so. ${ }^{100}$

The nature of a sovereign is such that "generalized grievances" in particular may survive under a special solicitude test. The disagreement between the justices reflects a more general tension in the case law whether and when a grievance fails simply because it is widely shared, and whether this rule derives from prudential considerations or is mandated by the Constitution. ${ }^{101}$ The majority was able to sidestep resolving these tensions. The Court was not dealing with an ordinary private litigant, but with a sovereign capable of asserting the rights of many people. The very nature of the parens patriae action is a generalized grievance and the purpose of the action is to vindicate public rights too diffuse to support individual standing. ${ }^{102}$ Environmental litigation has been plagued with the difficulties of overcoming the generalized grievance doctrine; Massachusetts $v$. EPA may change that. ${ }^{103}$ The end result:

97. Mank, Standing, supra note 63, at 1781-82.

98. Id. at 1783 (noting that forty-three states have elected attorneys general).

99. See Massachusetts v. EPA, 549 U.S. 497, 548 (2007) (Roberts, C.J., dissenting) ("The good news is that the Court's 'special solicitude' for Massachusetts limits the future applicability of the diluted standing requirements applied in this case."). The number of cases brought by states has historically been small, but may be increasing in number. Amy J. Wildermuth, Why State Standing in Massachusetts v. EPA Matters, 27 J. LAND RESOURCES \& ENVTL. L. 273, 287 \& nn.123-24 (2007) (collecting cases). Of course, the courts' concern with a flood of litigation is not necessarily well-founded, as "the experience of various states permitting taxpayer and even citizen suits casts doubt on the proposition that the courts will be swamped by litigation if private parties are not subject to standing limitations of some kind." John C. Reitz, Standing to Raise Constitutional Issues, 50 AM. J: COMP. L. 437, 454-55 (2002).

100. Mank, Standing, supra note 63, at 1781-82.

101. See generally Mark Gabel, Note, Generalized Grievances and Judicial Discretion, 58 HASTINGS L. J. 1331 (2007).

102. Zdeb, supra note 60 , at 1077 . The fact that criminal prosecutions are permitted in federal court defeats the idea that the Constitution prohibits a sovereign from enforcing public rights. See generally Edward A. Hartnett, The Standing of the United States: How Criminal Prosecutions Show that Standing Doctrine is Looking for Answers in All the Wrong Places, $97 \mathrm{MICH}$. L. REV. 2239 (1999).

103. Whether environmental harms fall within the generalized grievance doctrine is questionable. Environmental harms, it could be argued, are more similar to a mass tort 
given their sovereign status, states now play an expanded role in litigating climate change issues in federal court.

Finally, "special solicitude," indicates deference to the state's factual concerns. Massachusetts believed that it was suffering harm and that regulation of tailpipe emissions would solve the harm. It could not employ its sovereign prerogative and regulate, as it normally would, because its power has been preempted in this area. Therefore, it was forced to ask the Court to compel the agency charged with this responsibility to comply with federal law. The Court was reluctant to substitute its belief on the state of the world for Massachusetts's, with Massachusetts having made a reasoned judgment that the harm was significant, imminent, caused by emissions, and likely to be redressed with EPA regulation. Absent preemption, Massachusetts could determine facts about the world and act accordingly-and "empirical debates over the wisdom of [legislation] are not to be carried out in the federal courts." 104 With preemption, the standing doctrine puts courts in the situation of second-guessing a state's rational concerns about injury, beliefs as to causation, and convictions as to redressability that otherwise would be addressed through the democratic process within the state. "Special solicitude" removes this burden from the federal courts and returns it to the states. ${ }^{105}$ Thus, in undertaking the standing inquiry, courts will defer more to the factual assessments by sovereigns than they do to private litigants.

\section{INDIAN SOVEREIGNTY: ITS NATURE AND SCOPE}

But do Indian tribes get the benefits of "special solicitude" to the same extent as states? We think they ought to-at least in the environmental context-but before making that claim, we must examine the nature of tribal sovereignty in some detail. The Supreme Court gave Massachusetts a boost in the standing analysis

than the cases where every citizen suffers precisely the same injury. See Covington v. Jefferson County, 358 F.3d 626, 651-52 (9th Cir. 2004) (Gould, J., concurring). Moreover, "even more broadly distributed environmental harms are likely to have a disproportionate impact on the poor," and a growing body of literature identifies the uniquely severe harms experienced in tribal communities. Amy Sinden, In Defense of Absolutes: Combating the Politics of Power in Environmental Law, 90 IOWA L. REV. 1405, 1453 (2005).

104. Haw. Hous. Auth. v. Midkiff, 467 U.S. 229, 242-43 (1984).

105. This isn't to say that complete deference is warranted. But when faced with a close call, the Court chose to lessen the showing that a sovereign must make to establish standing. 
("special solicitude") on account of its sovereign nature. If Indian tribes hope to benefit from this same solicitude, they will need to demonstrate that they are, if not the equals of states in terms of sovereignty, not far behind. If tribes are not meaningfully sovereign, in other words, our argument has no legs.

Sovereignty has been called the "most commanding concept in all of Indian law." ${ }^{106}$ In its generic sense, the term sovereignty implies autonomous political power. ${ }^{107}$ However, sovereignty for tribes has usually fallen somewhat short. Tribes have never been placed on an equal footing with the federal government or foreign nations. Neither have domestic states, though, and we all consider them sovereign to one degree or another. _So what does sovereignty mean for tribes?

\section{A. History}

Answering that question demands a look to history. During the colonial era, European powers and their American agents treated Indian tribes as land-holders in name yet little more than occupants in substance. "The European nations presumed an exclusive right to deal with and extinguish the Indians' land titles." ${ }^{108}$ But this does not mean the conquering forces recognized no rules at all. In contrast to some of the Spanish conquistadores in Latin America who took the position that native land was theirs by divine right ${ }^{109}$ the British and French in North America accorded a

106. WILLIAM H. RODGERS, JR., ENVIRONMENTAL LAW IN INDIAN COUNTRY 5 (2007).

107. See AMERICAN HERITAGE Dictionary OF THE ENGLiSH LANGUAGE (4th ed. 2000) (describing sovereignty variously as "supremacy of authority or rule as exercised by a sovereign or sovereign state," "complete independence and self-government," and "a territory existing as an independent state"); see also Ring, supra note 4, at 160 ("At a minimum, a sovereign state is expected to have three elements: "territory, people, and a government.").

108. GETCHES, WILKINSON, \& WILLIAMS, supra note 5 , at 3.

109. See Daveed Gartenstein-Ross, No Other Gods Before Me: Spheres of Influence in the Relationship Between Christianity and Islam, 33 DENV. J. OF INT'L L. \& POL'Y 223, 269 (2005). Gartenstein-Ross describes the Spanish approach like this:

The early Spanish conquistadors arrived in the Americas armed with the Requerimiento (requirement), which they would read to the natives upon encountering them. The Requerimiento explained that the Pope, God's earthly representative, had granted the natives' land to the king of Spain, and that the natives should recognize the authority of the Pope and Spanish crown or else "with the help of God we shall forcefully enter your country and shall make war against you in all ways ... that we can." 
semblance of sovereignty to the tribes they "discovered." Though the practice was not uniform, the British and French would routinely make treaties with Indian tribes, thereby tacitly acknowledging their status as sovereign peoples. ${ }^{110}$ At the same time, however, it was clear from the start that the European nations viewed their native counterparts as lesser sovereigns.

Limiting the role of sovereignty was the notion of dependence. As European settlers displaced natives and decimated their numbers, it became plain that Indians were, in a practical sense at least, dealing with stronger sovereigns. ${ }^{111}$ Out of self-interest more than anything else, European discoverers would offer tribes protection from other colonizing forces. "The colonizing forces, and later the United States, agreed to continue such protection in return for the Indians' pledges of peace and fealty." ${ }^{112}$

During westward expansion the practice of negotiating treaties with Indian tribes flourished. ${ }^{113}$ The federal government (the

Id. (quoting DAVID H, GETCHES, CHARLES F. WILKINSON, \& ROBERT A. WILLIAMS, FEDERAL INDIAN LAW: CASES AND MATERIALS 48-49 (3d ed. 1993)). Portugal was no less extreme in its claim of religious entitlement. See id. This is not to suggest, however, that England and France were much more "civilized" in their approach to native peoples. Rather, it is only to state that the Anglo-Franco approach was different-if no less unjust-and that difference would bear legal consequences down the road.

110. Hope M. Babcock, A Civic-Republican Vision of 'Domestic Dependent Nations' in the Twenty-First Century: Tribal Sovereignty Re-envisioned, Reinvigorated, and Re-empowered, 2005 UTAH L. REV. 443, 457-58.

111. See Daniel Berkowitz \& Karen Clay, The Effect of Judicial Independence on Courts: Evidence from the American States, 35 J. LEGAL STUD. 399, 432 (2006) ("In practice, decimated by disease, given lower status than white colonists, and having had their land taken with little or no compensation, the Native Americans were not in any position to influence the evolution of the state legal system.")

112. GETCHES, WILKINSON, \& WILLIAMS, supra note 5, at 3 . However, for a short time after the Revolutionary War, the United States considered the tribes aligned with the British "conquered nations." This approach implied automatic transfer of title, but it was short-lived. See Scott A. Taylor, The Native American Law Opinions of Judge Noonan: Do We Hear the Faint Voice of Bartólome de las Casas?, 1 ST. THOMAS L. REV. 148, 159 (2003)

113. See Nell Jessup Newton, Federal Power over Indians: Its Sources, Scope, and Limitations, 132 U. PA. L. REv. 195, 200 (1984). Once again, the choice to make treaties was driven largely by utilitarian concerns:

In formulating federal policy toward Indian tribes in the early years of the Constitution, President Washington and Secretary of War Knox followed the policy promulgated by the British Crown-though not always followed by individual colonies-of dealing with Indian tribes as sovereign nations. Their principal reason was practical: earlier attempts by individual colonies and some states under the Articles of Confederation to assert power over Indian tribes, especially power to seize tribal lands, had caused conflicts. According to one historian, " $[t]$ he country, precariously perched among the sovereign nations of 
Constitution denied states this power) signed treaties securing large swaths of tribal land for white settlement. ${ }^{114}$ The deals were less than arms-length transactions. ${ }^{115}$ Federal authorities had the tribes between a rock and a hard place: they could do nothing to stop the wagon trains rolling across the western plains, so they claimed, and unless the tribes wanted to fight a futile battle and lose all their land in the process, they had better cede most (but not all) of their holdings peacefully. ${ }^{116}$ With some notable

the world, could not stand the expense and strain of a long drawn-out Indian war."

Id. (quoting Francis Prucha, AMERICAN INDIAN POLICY in THE Formative Years 44 (1962)) (footnotes omitted).

114. See, e.g., Howard J. Vogel, Healing the Trauma of America's Past: Restorative Justice, Honest Patrotism, and the Legacy of Ethnic Cleansing, 55 BuFf. L. REV. 981, 994-95 (2007) (discussing the land cession treaties struck between the Dakota and the United States in the mid-1800s.).

115. See, e.g., id. at 994 ("Most notorious among the land cession treaties were the two 'negotiated' in 1851 through a 'monstrous conspiracy' at Traverse des Sioux and Mendota .... Under these treaties, twenty-four million acres were ceded to the United States....) (footnote omitted).

116. See John E. Thorson, Ramsey Laursoo Kropf, Dar Crammond, \& Andrea K. Gerlak, Dividing Western Waters: A Century of Adjudicating Rivers and Streams, 8 DEN. WATER L. REv. 355, 372 (2005) ("The United States gave tribes a choice of sorts: keep the homeland and be overrun by white settlement, or move west."). One way or another, the United States government was going to stake out its territory from sea to shining sea. The push to the Pacific, under the banner of "manifest destiny," is the stuff of books, and so are the sufferings of Indians cast aside along the way. For a time, things looked relatively bright for the western tribes. Andrew Jackson, known to the eastern tribes as "Sharp Knife," convinced Congress to create a "permanent Indian frontier" in the early 1830 s "setting apart an ample district west of the Mississippi ... to be guaranteed to the Indian tribes, as long as they shall occupy it." DEE BROWN, BURY MY HEART AT WOUNDED KNEE: AN INDIAN HISTORY OF THE AMERICAN WEST 5-6 (1970) (internal quotations omitted). Shortly after the permanent frontier was created, however, white men moving into the territories of Wisconsin and Iowa led the government to shift the frontier line from the Mississippi to the 95th meridian. Id. at 6 . This would be the first of many such westward adjustments. When gold was discovered in California in 1848 (on the heels of U.S. acquisition of that territory by way of the Mexican-American War), easterners flocked to the West Coast by the thousands, driving through Indian Territory along the way and often taking up residence there. $I d$. at 8 . This was not supposed to happen according to the laws creating the permanent frontier. White persons were to be prohibited from settling in Indian Territory, they were not to trade in that land without a license, and, in fact, the U.S. military established forts along the Mississippi and Missouri Rivers to police these lines. Id. at 6 . But the gold rush and the desire for expansion were forces too tough to resist. White men were taking over Indian Territory, and the federal government was alright with that. It was, after all, the nation's "manifest destiny." Dee Brown is skeptical:

To justify these breaches of the "permanent Indian frontier," the policy makers in Washington invented "Manifest Destiny," a term which lifted land 
exceptions, ${ }^{117}$ the tribes capitulated. And they held on over the years more or less at the whim of the federal government. It was no misstatement, therefore, when the Supreme Court explained in 1978 that Indian tribes had lost some of their sovereignty "by virtue of their dependent status." 18

Of course, tribes weren't always so "dependent." They acquired that status through a campaign of warfare, deception, and legal fiction, and we should question whether sovereignty can be legitimately diminished in this manner. ${ }^{119}$ It is one thing if a people agree to compromise their sovereignty through a noncoercive accord (like agreeing to cede a sector of jurisdiction to the International Criminal Court ${ }^{120}$ ) or if a people are stripped of

hunger to a lofty plane. The Europeans and their descendants were ordained by destiny to rule all of America. They were the dominant race and therefore responsible for the Indians-along with their lands, their forests, and their mineral wealth. Only the New Englanders, who had destroyed or driven out all their Indians, spoke against Manifest Destiny.

Id. at 8 .

117. The Chiricahua Apache, led by Geronimo, held out against the federal government for over twenty-five years. BRITTON DAVIS, THE TRUTH ABOUT GERONIMO 207$10(1976)$

118. United States v. Wheeler, 435 U.S. 313, 326 (1978).

119. Professor William Bradford suggests as much in his article calling for Indian independence. See William Bradford, "Another Such Victory and We Are Undone": A Call to an American Indian Declaration of Independence, 40 TULSA L. REV. 71, 74-88 (2004) (chronicling the "destruction" of tribal sovereignty by federal Indian law). As Bradford sees it, the reasons for the diminishment of tribal sovereignty were as base they get:

Respect for mutual sovereignty, however, collapsed under the weight of white land hunger and burgeoning U.S. military capacity. Although prudence restrained U.S. aggression in the early decades of the republic, by the nineteenth century a majority of the U.S. population regarded the presumption of Indian sovereignty under international and domestic law as an obstacle to white notions of progress. It fell to federal Indian law to legitimate the violent expropriation of Indian lands and the destruction of rival polities within what would become the boundaries of the United States.

Id. at 77 (footnote omitted).

120. See Book Review, The Politics of Constructing the International Criminal Court, 12 YALE HUM. RTS. \& DEV. L.J. 275, 276 (2009) (stating that "the notion of state sovereignty $[w]$ as the key reason why earlier discussions of establishing an international criminal tribunal failed to lead to a permanent court like the ICC"); id. at 280 ("States' willingness to reduce their own sovereignty in deference to the ICC is not only grounded in the complementary nature of its jurisdiction but also in its permanence."); Karen J. Alter, Delegating to International Courts: Self-Binding vs. Other-Binding Delegation, 71 L. \& CONTEMP. PROBS. 37, 73 (2008) (discussing the "sovereignty costs" of delegation to international courts). 
some their sovereignty through a "just war" (the example of postWorld War II Germany comes to mind ${ }^{121}$ ). But it is entirely different if a people are coerced into ceding their sovereignty through trickery and deceit, or stripped of it through unjust warfare, as was the case for the American Indians. ${ }^{122}$ The Supreme Court has often taken the view that tribal sovereignty is diminished sovereignty without questioning how that came to be or, more importantly, whether that process of diminishment was legitimate. These are questions the Court should examine. When they are considered, the limitations of tribal sovereignty lose credibility.

121. See Michael J. Kelly, Political Downsizing: The Re-emergence of Self Determination, and the Movement Toward Smaller, Ethnically Homogenous States, 47 DRAKE L. REV. 209, 264 ("The post-World War II era saw ... the formal occupation of all of Germany for forty-five years . ... It was not until 1990 that a treaty was signed terminating the occupation and granting Germany 'full sovereignty over its external and internal affairs.'”) (footnote omitted). See also Robert J. Delahunty, The Battle of Mars and Venus: Why Do American and European Attitudes Toward International Law Differ, 4 LOY. U. CHI. INT'L L. REV. 11, 27 (2006) (commenting on the decline of nationalism and the importance of sovereignty in postWorld War II Europe, particularly in Germany). Delahunty asserts that

The end of the Second World War led to the decline of nationalism all over Western Europe, but above all in Germany. As Russell Hittinger puts the point, "In 1945, after two world wars, the crown jewel of modernity-the sovereign nation state-was brought before the bar of moral judgment. The Protestant theologian, Karl Barth aptly called this the era of 'disillusioned sovereignty.' . . . While the post-War phenomenon of the erosion of national feeling and national sovereignty has by no means been confined to Europe, it has been felt unusually keenly there.

\section{Id. (footnotes omitted).}

122. Wars of conquest cannot be, under any accepted definition, "just wars." See Major Jennifer B. Bottoms, When Close Doesn't Count: An Analysis of Israel's Jus ad Bellum and Jus in Bello in the 2006 Israel-Lebanon War, 2009 (April) ARMY LAWYER 23, 27-30 (discussing classic definitions of just war theory from Cicero, St. Augustine, and St. Thomas Aquinas). A "just war" requires, first and foremost, a just case, such as self-defense, recovering stolen goods or property, avenging a wrong, or taking action against a nation where that nation has refused to address a wrong committed by one of its citizens. Id.; see also Carsten Stahn, Jus Post Bellum: Mapping the Discipline(s), 23 AM. U. INT'L L. REv. 311, 336 (2008) (explaining that "classical principles of just war theory" include "just cause, right intention, public declaration, legitimate authority, discrimination and proportionality"). Conquest and expansion for their own sake do not cut it. See Michael Walzer, ARGUING ABOUT WAR xi (2004) ("Aggressive wars, wars of conquest, wars to extend spheres of influence and establish satellite states, wars for economic aggrandizement-all these are unjust wars.") 
B. The Law

\section{The Marshall Trilogy.}

The law concerning Indian sovereignty more or less tracked the historical narrative. Many of the fundamental principles underlying Indian law were framed by Chief Justice John Marshall. From 1823 to 1832 , the Supreme Court decided three cases, Johnson v. M'Intosh, 21 U.S. (8 Wheat) 543 (1823), Cherokee Nation v. Georgia, 30 U.S. (5 Pet.) 1 (1831), and Worcester v. Georgia, 31 U.S. (6 Pet.) 515 (1832), the so-called "Marshall Trilogy," which would serve as the legal foundation for federal Indian policy in the years to come. ${ }^{123}$

The legal justification for taking over Indian lands came to be known as the "doctrine of discovery." In Johnson v. M'Intosh, Marshall described this doctrine, long employed by conquering European nations, and determined that the United States had adopted it. ${ }^{124}$ Under this doctrine, the discovering nation inherited "the sole right of acquiring soil from the natives." ${ }^{125}$ To avoid conflicting settlements and war, the European nations in North America all agreed to this principle. ${ }^{126}$ According to Marshall, the rights of Indians were not "entirely disregarded," but "their rights to complete sovereignty, as independent nations, were necessarily diminished, and their power to dispose of the soil at their own will, to whomsoever they pleased, was denied by the original fundamental principle, that discovery gave exclusive title to those who made it." ${ }^{127}$ When the colonies won independence from the British, they took the latter's property rights gained through discovery and conquest. ${ }^{128}$ Ultimately, these rights passed to the United States. ${ }^{129}$ Under the doctrine, the United States holds fee

123. Mathew L.M. Fletcher, The Iron Cold of the Marshall Trilogy, 82 N.D. L. REv. 627, 627-28 (2006) [hereinafter Fletcher, Marshall Trilogy]; see also Rebecca A. Hart \& M. Alexander Lowther, Honoring Sovereignty: Aiding Tribal Efforts to Protect Native American Women from Domestic Violence, 96 CAL. L. REV. 185, 199 (2008) (stating that these cases "outline the fundamental principles of federal Indian law").

124. Johnson v. M'Intosh, 21 U.S. (8 Wheat.) 543, 584-87 (1823)

125. Id. at 573 .

126. Id.

127. Id. at 574 .

128. See Hope M. Babcock, Reserved Indian Water Rights in Riparian Jurisdictions: Water, Water Everywhere, Perhaps Some Drops for Us, 91 CORNELL L. REv. 1203, 1254 (2006) (explaining that "fee title to Indian land was first vested in the discovering European nation, and later in state sovereigns").

129. See Johnson, 21 U.S. ( 8 Wheat.) at 587 ("The United States, then, have 
title to indigenous lands, but Indian tribes have the right to use and possess their lands subject to conquest or purchase by the government. ${ }^{130}$ However reviled it may be, ${ }^{131}$ the doctrine of discovery remains good law, ${ }^{132}$ informing decisions to this very day. ${ }^{133}$ As it relates to Massachusetts v. EPA, courts have pointed to the doctrine of discovery-or at least its underlying principleswhen asserting that tribal sovereignty is of a lesser rank. ${ }^{194}$ But again, we should question the doctrine insofar as it is founded on a presumption of Indian "inferiority." 185

Marshall penned the lead opinion in Cherokee Nation v. Georgia seven years later, in $1831 .{ }^{136}$ The holding is plain enough-Indian tribes do not qualify as "foreign State[s]" within the meaning of the Constitution. ${ }^{137}$ However, Marshall was not willing to deprive tribes of all recognition as political entities. Tribes were "states," he concluded, but of a type never before envisioned. He observed

unequivocally acceded to that great and broad rule by which its civilized inhabitants now hold this country. ... They maintain, as all others have maintained, that discovery gave an exclusive right to extinguish the Indian title of occupancy, either by purchase or by conquest ...."); see also Babcock, supra note 128, at 1253 ("[T] ribal rights of occupancy became the exclusive province of federal law when the Constitution was signed.").

130. County of Oneida v. Oneida Indian Nation, 470 U.S. 226, 234 (1985).

131. See Blake A. Watson, John Marshall and Indian Land Rights: A Historical Rejoinder to the Claim of "Universal Recognition" of the Doctrine of Discovery, 36 SETON HALL. L. REv. 481 (2006) (contending that the doctrine of discovery was not nearly so accepted as Chief Justice Marshall professed); David Wilkens, Quit-Claiming the Doctrine of Discovery: A TreatyBased Reappraisal, 23 OKLA. CITY U. L. REV. 277 (1998) (criticizing the doctrine of discovery on legal and policy grounds); $c f$. STUART BANNER, HOW THE INDIANS LOST THEIR LAND: LAW AND POWER ON THE FronTIER 12 (2005) (observing that, at least prior to the Seven Years War, England "treated the Indians as owners of their land" as a matter of "overall English colonial land policy").

132. See Andrew Huff, Indigenous Land Rights and the New Self-Determination, 16 COLO. J. INT'L ENVTL. L. \& POL'Y 295, 299 (2005).

133. See, e.g., Del. Nation v. Pennsylvania, 446 F.3d 410, 415-16 (3d Cir. 2006); Seneca Nation of Indians v. New York, 382 F.3d 245, 260-72 (2d. Cir. 2004); W. Mohegan Tribe and Nation v. Orange County, 395 F.3d 18, 22-23 (2d Cir. 2004).

134. See, e.g., Seneca Nation of Indians v. New York, 206 F. Supp. 2d 448, 502-06 (W.D.N.Y. 2002) (describing the doctrine of discovery and its impact upon the strength of tribal title to Indian lands).

135. See Bradford, supra note 119 , at 78 ("While Marshall admitted that this argument was 'opposed to natural right' and contrary to principles of justice, he drew from the doctrine of stare decisis, comparisons to the practice of other states, and the presumption of Indian 'inferiority' to find that 'if [such arguments] be indispensable to that system under which the [United States] has been settled, [they] . . certainly cannot be rejected by Courts.'") (quoting Johnson v. M'Intosh, 21 U.S. (8 Wheat.) 543, 591-92 (1823) (footnotes omitted)).

136. Cherokee Nation v. Georgia, 30 U.S. (5 Pet.) 1 (1831).

137. Id. at 20. 
that the Cherokee people had to be deemed a state because " $[t]$ he numerous treaties made with them by the United States recognize them as a people capable of maintaining the relations of peace and war, of being responsible in their political character for any violation of their engagements, or for any aggression committed on the citizens of the United States by any individual of their community." 138 But the reality of the situation meant that tribes were not states like Britain and France (and neither like New York and Virginia). In Marshall's view, the tribes' relationship to the United States "resemble[d] that of a ward to his guardian," and therefore they were more properly seen as "domestic dependent nations." ${ }^{139}$ The Court would later rely on this concept to create the doctrines of plenary power and the trust relationship. ${ }^{140}$ Like the doctrine of discovery, however, the concept of tribes as "domestic dependent nations" loses credibility along with its theoretical underpinning: that native peoples are somehow entitled to less respect as sovereigns than whites. Although the Cherokee Nation decision recognized tribes as sovereigns to some degree-capable of limited self-government and interaction with other nations-we should not be too satisfied. There is a strong argument to be made that tribal sovereignty should never have been so degraded, an argument that supports special solicitude for tribes in that their claims to sovereignty are stronger than the United States has ever recognized.

The last of the trilogy is Worcester $v$. Georgia ${ }^{141}$ A landmark decision on federalism, Worcester addressed the extent to which states have power to regulate tribes. Georgia had enacted laws that purported to extinguish the Cherokee Nation, distribute its land to whites, nullify Indian customs and laws, and establish Georgia law as the sole governing authority. The Supreme Court struck down the laws five to one. Announcing the Court's opinion, Chief Justice Marshall offered a stern reminder to those who would question Indian sovereignty: "The Indian nations had always been considered as distinct, independent political communities, retaining their original natural rights, as the undisputed possessors of the soil, from time immemorial ... . The very term 'nation,' so generally applied to them, means 'a people distinct from

138. Id. at 16 .

139. Id. at 17 .

140. Fletcher, Marshall Trilogy, supra note 123, at 653.

141. Worcester v. Georgia, 31 U.S. (6 Pet.) 515 (1832). 
others." ${ }^{\prime 142}$

The upshot of this, in Marshall's view, was that only the federal government had power to regulate tribes:

The Cherokee nation, then, is a distinct community, occupying its own territory, with boundaries accurately described, in which the laws of Georgia can have no force, and which the citizens of Georgia have no right to enter, but with the assent of the Cherokees themselves, or in conformity with treaties, and with the acts of congress. The whole intercourse between the United States and this nation, is by our constitution and laws, vested in the government of the United States. ${ }^{143}$

Again, like M'Intosh and Cherokee Nation, Marshall's opinion in Worcester was both a win and a loss for tribal sovereignty. On the plus side, Worcester recognized that states have no power to regulate Indian tribes, essentially placing them at an equal mark on the sovereignty scale. ${ }^{144}$ On the negative side, however, the Marshall Court assumed almost $a$ priori that tribal sovereignty could not equal that of the United States. For purposes of our argument, however, Worcester must be considered a victory. In placing tribes and states on a more or less equal footing in terms of sovereignty, Worcester supports the claim that tribes should be entitled to the same "special solicitude" as states.

2. Beyond the Marshall Trilogy: Acknowledging differences between tribal and state sovereignty.

After reading these cases, one might deem it a foregone conclusion that tribes are as sovereign as domestic states, if not more so. ${ }^{145}$ But our critics will be quick to observe that this was

142. Id. at 559 .

143. Id. at 561 .

144. See Babcock, supra note 110 , at 448 ("The Cherokee finally prevailed in Worcester, and proponents of tribal sovereignty consider the decision to be among the few high water marks in Indian law because it recognized and affirmed the existence of tribal sovereignty, albeit a sovereignty cabined by the greater authority of the federal government.") (footnote omitted).

145. See Anne E. Tweedy, Connecting the Dots Between the Constitution, the Marshall Trilogy, and United States v. Lara: Notes Toward a Blueprint for the Next Legislative Restoration of Tribal Sovereignty, 42 U. MICH. J. L. REFORM 651, 668 (2009) ("[T]he Trilogy decisions do, in many ways, provide a view of tribal sovereignty that is functionally robust ...."). 
hardly the Marshall Court's intention, ${ }^{146}$ and more recent decisions preclude any straight-faced claim to that effect. We acknowledge that tribal sovereignty is, at least under recent jurisprudence, limited in significant ways; it does not track state sovereignty in every detail. Despite the differences, however, we believe tribes are sufficiently sovereign to deserve special solicitude in the standing analysis. In many ways, in fact, special solicitude makes even more sense for tribes. But first let us review some of the objections our critics might make.

Our critics might begin by asking us to consider tribal authority over nonmembers, and they would have a point: In Oliphant $v$. Suquamish Tribe, 435 U.S. 191 (1978), the Court held that tribes lack criminal jurisdiction over nonmembers, even when they commit crimes against Indians on Indian land. ${ }^{147}$ The Court went a

146. Consider, for instance, the bigotry underlying the Marshall Trilogy. These cases (with the exception of Worcester) were premised on the offensive notion that Indians, as "savages," were fundamentally inferior to white people. See Robert A. Williams, Jr., Columbus's Legacy: Law as an Instrument of Racial Discrimination Against Indigenous Peoples' Rights of Self-Determination, 8 ARIZ. J. INT'L \& COMP. L. 51, 70 (1991). And, disturbingly, that thinking can be seen even in modern decisions. See generally ROBERT A. WILLIAMS, JR., LIKE A LOADED WEAPON: THE REHNQUIST COURT, INDIAN RIGHTS AND THE LEGAL HISTORY OF RACISM IN AMERICA (2005). In 1980, Justice Rehnquist dissented from the decision in United States v. Sioux Nation of Indians, 448 U.S. 371, 424 (1980). Although his view did not win the day, it is shocking nonetheless. To support his position, Rehnquist quoted with approval a historian's view that the Plains Indians "'lived only for the day, recognized no rights of property, robbed or killed anyone if they thought they could get away with it, inflicted cruelty without a qualm, and endured torture without flinching.' Id. at 436-37 (quoting S. MORISON, THE OXFORD HISTORY OF THE AMERICAN PEOPLE 539-540 (1965)). This is not to suggest that modern Indian law is entirely predicated on racism. Much of it has to do with political inertia and the realities of contemporary life. Few would seriously argue that all land be returned to the ancestors of the original inhabitants, though there have been noteworthy cases on that front. See, e.g., Cayuga Indian Nation v. Pataki, 413 F.3d 266 (2d Cir. 2005). However, one cannot help but look at Indian law-past and current-and detect real vestiges of racism. Suffice it to say that Indian sovereignty has been limited, and many of those limitations flow from a dubious worldview.

147. Oliphant v. Suquamish Tribe, 435 U.S. 191, 212 (1978); see also Nevada v. Hicks, 533 U.S. 353, 358 (2001). Oliphant is a disturbing read. Then-Associate Justice Rehnquist, writing for the Court, justified the decision by pointing to jurisprudence suggesting Indians have limited power because that is all they can handle:

In In re Mayfield, the Court noted that the policy of Congress had been to allow the inhabitants of the Indian country "such power of self-government as was thought to be consistent with the safety of the white population with which they may have come in contact, and to encourage them as far as possible in raising themselves to our standard of civilization.

Oliphant, 435 U.S. at 204 (quoting In re Mayfield, 141 U.S. 107, 115-16 (1891)). 
step further in United States v. Montana, 450 U.S. 544 (1981), deciding that the Crow Tribe could not regulate hunting and fishing by nonmembers on land they held in fee simple, despite that the land was located within the Crow Reservation. ${ }^{148}$ The Court came to this conclusion based on a narrow view of tribal power: at least where nonmembers are involved, "exercise of tribal power beyond what is necessary to protect tribal self-government or to control internal relations is inconsistent with the dependent status of the tribes, and so cannot survive without express congressional delegation." 149

In response, however, we would ask our critics to recognize that Oliphant and Montana are exceptions to the general jurisprudence-jurisprudence that respects tribal sovereignty. As Justice Blackmun put it, concurring in part and dissenting in part in 1989's Brendale $v$. Confederated Tribes, the jurisprudence is "remarkable" in that, "except for those few aspects of sovereignty recognized in the [Marshall Trilogy] as necessarily divested, the Court only once prior to Montana . . . has found an additional sovereign power to have been relinquished upon incorporation." And to the extent Montana limited tribal civiljurisdiction over nonmembers, it was particularly exceptional. In cases following Montana, the Court "held without equivocation that tribal civil jurisdiction over non-Indians on reservation lands is not an aspect of tribal sovereignty necessarily divested by reason of the tribes' incorporation within the dominant society." 151 Admittedly, there is tension in the case law here. But it is best resolved by Justice Blackmun's take: In Montana, "the Court simply missed its usual way." 152

In keeping with the first objection, nevertheless, our detractors will press on by noting that state courts enjoy relatively broad jurisdiction in comparison with their tribal counterparts. As courts of general jurisdiction, state courts have jurisdiction over all actions save those committed to the exclusive jurisdiction of

148. Montana, 450 U.S. at 564-65.

149. Id. at 564 .

150. Brendale v. Confederated Tribes and Bands of Yakima, 492 U.S. 408,453 (Blackmun, J., concurring in part and dissent in part). When Justice Blackmun mentioned the one occasion "prior to Montana," he was referring to Oliphant. Id.

151. Id. at 454 (Blackmun, J., concurring in part and dissenting in part) (discussing Merrion v. Jicarilla Apache Tribe, 455 U.S. 130 (1982), and Iowa Mutual Ins. Co. v. LaPlante, 480 U.S. 9 (1987)).

152. Id. at 455 (Blackmun, J., concurring in part and dissenting in part). 
federal courts. ${ }^{153}$ And they have personal jurisdiction over any defendant with "minimum contacts" with the forum state. ${ }^{154}$ All told, jurisdiction in state court is the rule rather than the exception; it is often the opposite in tribal court. ${ }^{155}$

The same dynamic is at least facially true, we concede, in the context of regulatory power. Whereas state sovereignty is limited only where preempted by federal law, a "tribe's sovereign interests are now confined to managing tribal land, 'protect[ing] tribal selfgovernance,' and 'control[ling] internal relations."'56 But the

153. Tafflin v. Levitt, 493 U.S. 455,458 (1990).

154. Int'l Shoe Co. v. Washington, 326 U.S. 310,316 (1945)

155. The Court made this point forcefully in Nevada v. Hicks, 533 U.S. 353 (2001), where it rejected the argument that a tribal court was a court of "general jurisdiction" sufficient to adjudicate a claim brought under 42 U.S.C. $\$ 1983$. Distinguishing tribal courts from state courts, the majority wrote:

Respondents' contention that tribal courts are courts of "general jurisdiction" is also quite wrong. A state court's jurisdiction is general, in that it 'lays hold of all subjects of litigation between parties within its jurisdiction, though the causes of dispute are relative to the laws of the most distant part of the globe.' Tribal courts, it should be clear, cannot be courts of general jurisdiction in this sense, for a tribe's inherent adjudicative jurisdiction over nonmembers is at most only as broad as its legislative jurisdiction.

Id. at 367 (citations omitted).

156. Plains Commerce Bank v. Long Family Lands \& Cattle Co., 128 S. Ct. 2709, 2723 (2008). In Plains Commerce Bank, a case involving both adjudicatory and regulatory power, the Supreme Court gave these categories a narrow construction. A non-Indian bank sold land it owned in fee simple on the Cheyenne River Sioux Indian Reservation to other nonIndians. Id. at 2714-15. But an Indian family, the Longs, had been leasing the land with an option to buy. Id. at 2715 . The Longs claimed that the bank discriminated against them by selling the land to the non-members on terms more favorable than they had received, and they instituted an action to this effect in tribal court. Id. at 2715-16. The court overruled an objection to its jurisdiction, and the jury found in favor of the Longs. Id. at 2716. The Bank then sued in district court seeking a declaration that the tribal judgment was void for want of jurisdiction. Id. The district court rejected this argument, and the Eighth Circuit affirmed, concluding that tribes have authority to regulate the business conduct of nonmembers who voluntarily interact with tribal members. Id. The Supreme Court disagreed that tribal authority was so broad. The Court stated that, under Montana, there are only two exceptions to the rule that tribes lack authority to regulate the conduct of nonmembers on land they hold in fee. Id. at 2719-20. The first is the power to regulate the conduct of nonmembers "who enter consensual relationships with the tribe or its members, through commercial dealing, contracts, leases, or other arrangements." Id. at 2720 (internal quotations omitted) (quoting Montana, 450 U.S. at 565). The second exception is the ability to "exercise civil authority over the conduct of non-Indians on fee lands within the reservation when that conduct threatens or has some direct effect on the political integrity, the economic security, or the health or welfare of the tribe." Id. at 2720 (internal quotations omitted) (quoting Montana, 450 U.S. at 566). The Supreme Court held that the Longs' discrimination suit met neither of these exceptions. Construing the 
contrast here isn't as great as it seems. Federal preemption of state law is so common that if you manipulated the Court's words to describe state sovereignty ("a [state]'s sovereign interests are now confined to managing [state] land, 'protect[ing] [state] selfgovernance,' and 'control[ling] internal relations"') not many would blink an eye. ${ }^{157}$

Another vestige of sovereignty that marks a distinction between tribes and states (in this case, in favor of tribal sovereignty) is the power to enter into treaties with the federal government. Article II of the Constitution instills the President with the "Power, by and with the Advice and Consent of the Senate, to make Treaties, provided two thirds of the Senators present concur." 158 Although this clause does not mention tribes as such, it has long been acknowledged that they come within its ambit. ${ }^{159}$ Indeed, because

discrimination suit narrowly, the Court interpreted the case as "challeng[ing] a nonIndian's sale of non-Indian land." Id. at 2720. The Court distinguished this-the sale of land-from conduct on land within a reservation, stating that tribes "may regulate nonmember behavior [even on non-Indian fee land] that implicates tribal governance and internal relations," but they have no power to regulate the sale of land as such. $I d$. at 2723 . It seems to us that this was not so much a fair construction of the nature of the action as it was emblematic of the Court's recent antagonism to any real conception of tribal sovereignty. To put it mildly, the Plains Commerce Court held once again that " $[t]$ he sovereign authority of Indian tribes is limited in ways state and federal authority is not." Id. at 2726 .

157. See John P. Dwyer, The Role of State Law in an Era of Federal Preemption: Lessons from Environmental Regulation, 60 L. \& CONTEMP. PROBS. 203, 205 (1997) (“[The role of states in environmental regulation] is increasingly restricted to those areas not yet subject to extensive federal regulation ... and to the implementation and enforcement of permits issued pursuant to federal standards and procedures."); Robert A. Schapiro, Federalism as Intersystemic Governance: Legitimacy in a Post-Westphalian World, 57 EMORY L. J. 115, 124 (2007) (explaining that the Supreme Court has in recent times developed a "robust" preemption doctrine). See generally Catherine M. Sharkey, Preemption by Preamble: Federal Agencies and the Federalization of Tort Law, 56 DEPAUL L. REV. 227 (2007) (noting the increase in federal preemption of state tort law).

158. U.S. CONST. art. II, $\$ 2$, cl. 2.

159. See United States v. Forty-Three Gallons of Whiskey, 93 U.S. 188 (1876); Johnson v. McIntosh, 21 U.S. (8 Wheat.) 543, 593-94 (1823); Thomas H. Pacheco, Indian Bedlands Claims: A Need to Clear the Waters, 15 HARV. ENVrL. L. REv. 1, 6 n.26 (1991) ("Under the treaty clause of the United States Constitution, the national government is given the exclusive power to enter into treaties with Indian Tribes. Congress ended the practice of treaty making by statute in 1871." (citation omitted)); Joseph William Singer, Nine-Tenths of the Law: Title, Possession and Sacred Obligations, 38 CONN. L. REv. 605, 614 (2006) ("The treaty clause made no distinction between treaties made with Indian nations and other nations and was the source of federal power to negotiate treaties with Indian nations."); see also Phillip M. Kannan, Reinstating Treaty-Making with Native American Tribes, 16 WM. \& MARY BILL RTS. J. 809, 813 (2008) ("[T] he authority of Indian tribes to enter into treaties with . . . the United States is a prerequisite to the validity of land title in the United States."). 
the United States acquired so much land by striking treaties with native tribes, the legitimacy of title rests on a presumption of tribal power to make these compacts with the federal government.

States, on the other hand, cannot enter into treaties with each other, the federal government, or foreign nations. ${ }^{160}$ At a basic level, this implies that Indian tribes have more sovereignty than states. Cutting in the other direction, though, our critics would observe, is more recent history and the emasculation of the treaty power by Congress. A treaty has not been struck between the United States and an Indian tribe under the Treaty Clause since the passage of the Indian Appropriation Act of 1871. ${ }^{161}$ That Act provides that "no Indian nation or tribe within the territory of the United States shall be acknowledged or recognized as an independent nation, tribe, or power with whom the United States may contract by treaty . . ."162 While the Act does not purport to invalidate prior treaties, ${ }^{163}$ it has put a stop to the practice, a policy choice that has not been revisited for over 135 years. Since 1871, the federal government has dealt with tribes strictly through executive agreements and legislation. ${ }^{164}$ On the other hand, the Indian Appropriation Act notwithstanding, the President must theoretically retain the authority to make treaties with tribes with the advice and consent of the Senate. Although the Act appears to extinguish this authority, that view cannot be reconciled with the fact that an amendment is needed to limit powers enumerated in the Constitution..$^{165}$ But even if the Act is taken at face value, it at worst brings tribes down to the level of states. ${ }^{166}$

Which brings us to Congress's "plenary power" to regulate

160. U.S. CONST. art. I, $\S 10, \mathrm{cl}$. 1. Tribes also lack the power under the Constitution to form treaties with foreign nations. See Johnson, 21 U.S. (8 Wheat) at 573; Kristen A. Carpenter, Real Property and Peoplehood, 27 STAN. ENVTL. L.J. 313, 349 (2008). But this was not the case prior to the Constitution, when tribes regularly struck treaties with European nations. See Kannan, supra note 159 , at 813.

161. Kannan, supra note 159, at 818. Among other things, the Indian Appropriation Act expressed Congress's resolution that Indian tribes were no longer entities "with whom the United States may contract by treaty." 25 U.S.C. $\$ 71$ (Westlaw 2009). The Act did not however, "invalidate[] or impair[]" existing treaties. Id.; see also United States v. Lara, 541 U.S. 193, 201 (2004).

162. 25 U.S.C. $\$ 71$.

163. Id.

164. Kannan, supra note 159 , at 818 .

165. But see Organized Vill. of Kake v. Egan, 369 U.S. 60, 72 (1962). See generally Browsher v. Synar, 478 U.S. 714 (1986)..

166. See U.S. CONST. art. I, $\S 10$, cl. 1 (denying states the power to enter into treaties). 
Indians, perhaps the most serious hurdle to advancing a robust conception of tribal sovereignty. ${ }^{167}$ This power is said to flow primarily from the Indian Commerce Clause, under which Congress has power " $[t]$ o regulate Commerce with . . . . the Indian Tribes." ${ }^{\text {6168 }}$ Although it seems questionable to derive plenary power from this language, ${ }^{169}$ it is not all that remarkable-look at the broad grant of power under the interstate portion of the Commerce Clause. ${ }^{170}$ Of course, no one would assert that Congress has plenary power to regulate states by virtue of the Commerce Clause, rendering the textualist objection that much stronger in the case of Indian tribes. ${ }^{171}$ Whatever strength this argument may have, however, it is black-letter law that Congress has the power to abrogate any treaty it desires, limit a tribe's power to govern itself, and renege on a previous recognition of a tribe as a legal entity. ${ }^{172}$ Perhaps recognizing the difficulty of deriving plenary power from the Indian Commerce Clause, the Supreme Court has identified the Necessary and Proper Clause, the Supremacy Clause, the Treaty Clause, the War Power, and the Property Clause as

167. See, e.g., Cotton Petroleum Corp. v. New Mexico, 490 U.S. 163, 192 (1989).

168. U.S. CONST. art. I, $\S 8$, cl. 3. The Supreme Court has also identified the Treaty Clause, the War Powers Clause, and the Property Clause as contributing to Congress's plenary power to regulate Indian affairs. United States v. Lara, 541 U.S. 193, 200 (2004).

169. See Mathew M. Fletcher, Preconstitutional Federal Power, 82 TUL. L. Rev. 509, 522 (2007) [Hereinafter Fletcher, Federal Power] ("The text of the Indian Commerce Clause suggests (perhaps) that congressional authority in the field of Indian affairs is less than plenary, if one accepts the argument that 'commerce' does not include the entire field ... .); id. at 565 (observing that scholarship suggests "this is a weak source of authority").

170. See Gonzales v. Raich, 545 U.S. 1, 17 (2005) (confirming congressional "power to regulate purely local activities" that substantially impact interstate commerce).

171. In Lara, Justice Thomas took issue with the majority's unquestioning acceptance of the plenary-power doctrine, writing:

I do, however, agree that this case raises important constitutional questions that the Court does not begin to answer. The Court utterly fails to find any provision of the Constitution that gives Congress enumerated power to alter tribal sovereignty. The Court cites the Indian Commerce Clause and the treaty power. I cannot agree that the Indian Commerce Clause "provide[s] Congress with plenary power to legislate in the field of Indian affairs." At one time, the implausibility of this assertion at least troubled the Court, and I would be willing to revisit the question.

Lara, 54 U.S. at 224 (Thomas, J., concurring) (citation omitted) (quoting Cotton Petroleum, 490 U.S. at 192.)

172. GeTCHES, WILKINSON, \& WILLIAMS, supra note 5 , at 5 . 
supplementary sources of authority. ${ }^{173}$ We admit that congressional authority to regulate states is far more limited. Congress's power under the Commerce Clause is extremely broad, ${ }^{174}$ even after United States v. Lopez, ${ }^{175}$ as is its spending power. ${ }^{176}$ Yet the Tenth Amendment, ${ }^{177}$ state sovereign immunity, ${ }^{178}$ and political pressure from the reinvigorated states-rights movement ${ }^{179}$ all combine to stem the tide of congressional overreaching into state affairs.

\section{CONNECTING THE DOTS}

\section{A. Tribes Are Nevertheless Sovereign}

The shortcomings of tribal sovereignty notwithstanding, tribes are sovereign in meaningful ways. Legally and sociologically, tribes

173. Fletcher, Federal Power, supra note 169, at 562; Robert J. Miller, The Doctrine of Discovery in American Indian Law, 42 IDAHO L. REV. 1, 105-06 (2005).

174. See Gonzales v. Raich, 545 U.S. 1 (2005); New York v: United States, 505 U.S. 144 (1992); South Dakota v. Dole, 483 U.S. 203 (1987); see also DougLAS W. KMIEC \& STEPHEN B. PRESSER, THE AMERICAN CONSTTTUTIONAL ORDER: HISTORY, CASES, AND PHILOSOPHY 208 (1998) (explaining that these cases effectively authorize Congress to commandeer states as agents of the federal government).

175. United States v. Lopez, 514 U.S. 549, 564 (1995); see also H. Jeffrey Moulton, The Quixotic Search for a Judicially Enforceable Federalism, 83 MINN. L. REv. 849, 890 (1999) ("In the end, ... the Court's reaffirmance of cases like Wickard $v$. Filburn and Katzenbach $v$. McClung suggests that as a practical matter congressional power is not much diminished. Perhaps the best description of Lopez's significance is as one in a series of periodic reminders to Congress that its powers are not plenary....").

176. See Raich, 545 U.S. at 17; Jesse H. Choper \& John C. Yoo, The Scope of the Commerce Clause After Morrison, 25 OKLA. CITY U. L. REV. 843, 857 (2000) ("Given the broad sweep of the spending power as currently construed, the federal government would quite clearly have the ability to evade the direct limits on its Commerce Clause powers."); Nelson Lund, Fig Leaf Federalism and Tenth Amendment Exceptionalism, 22 CONST. COMMENT. 11,15 (2005) ("The reach of Lopez and Morrison may turn out to be extremely narrow. That at least appears to be the implication of the 6-3 decision in Gonzales $v$. Raich...."); id. at 17 ("[F]ederal authority under the Commerce Clause and the so-called Spending Clause is so broad and flexible that Congress should be able rather easily to induce the states to take virtually any action that New York and Printz forbid the federal legislature to command directly.").

177. U.S. CONST, amend. X.

178. See, e.g., Fed. Mar. Comm'n v. S.C. State Ports Auth., 535 U.S. 743, 760 (2002) (holding that "state sovereign immunity bars [an administrative agency] from adjudicating complaints filed by a private party against a nonconsenting State"); Seminole Tribe v. Florida, 517 U.S. 44, 47 (1996) ("We hold that notwithstanding Congress' clear intent to abrogate the States' sovereign immunity, the Indian Commerce Clause does not grant Congress that power, and therefore [the Indian Gaming Regulatory Act] cannot grant jurisdiction over a State that does not consent to be sued.").

179. See Roger F. Nagel, The Future of Federalism, 46 CASE W. RES. L. REV. 643, 645 (1996) (“States' rights seem at least momentarily ascendant.") 
possess enough attributes of sovereign entities that they ought to enjoy special solicitude the same as Massachusetts or any other state. And the sovereignty that tribes have is similar to states in ways relevant to the standing analysis.

To begin with, tribes are similar to states in terms of sovereign immunity in federal court. ${ }^{180}$ This immunity from suit is a crucial aspect of sovereignty, ${ }^{181}$ and both tribes and states enjoy similar protections under this doctrine. ${ }^{182}$ Neither tribes nor states are required to defend a suit absent their consent, and any such consent must be "unequivocally expressed." ${ }^{183}$ And because tribal and state sovereign immunity is a defense to liability as well as protection from suit, both tribes and states may appeal an adverse determination of sovereign immunity on an interlocutory basis. ${ }^{184}$ Sovereign immunity has long benefitted the sovereign defendants by providing that they need not answer to a federal court when they do not want to. "Special solicitude" in the standing analysis provides the parallel benefit to the sovereign plaintiff, granting it the ability to invoke the aid of the federal judiciary when it so desires.

Of course, it is true that Congress is limited in its ability to abrogate state sovereign immunity, ${ }^{185}$ while tribal sovereign

180. Santa Clara Pueblo v. Martinez, 436 U.S. 49, 58 (1978) ("Indian tribes have long been recognized as possessing the common-law immunity from suit traditionally enjoyed by sovereign powers.").

181. Alden, 527 U.S. at 716 ("'It is inherent in the nature of sovereignty not to be amenable to the suit of an individual without its consent."') (quoting THE FEDERALIST NO. 81 (Alexander Hamilton)).

182. E.g., Vann v. Kempthorne, 534 F.3d 741, 746 (D.C. Cir. 2008) ("As sovereigns, Indian tribes enjoy immunity against suits. This immunity flows from a tribe's sovereign status in much the same way as it does for the States and for the federal government." (citations and footnotes omitted)).

183. Santa Clara Pueblo, 436 U.S. at 58 (internal quotations omitted) (quoting United States v. Testan, 424 U.S. 392, 399 (1976)).

184. P.R. Aqueduct \& Sewer Auth. v. Metcalf \& Eddy, Inc., 506 U.S. 139, 144 (1993) (states); Burlington N. \& Santa Fe Ry. Co. v. Vaughn, 509 F.3d 1085, 1091 (9th Cir. 2007) (tribes); Osage Tribal Council v. U.S. Dep't of Labor, 187 F.3d 1174, 1179-80 (10th Cir. 1999) (same); Tamiami Partners v. Miccosukee Tribe of Indians, 63 F.3d 1030, 1050 (11th Cir. 1995) (same).

185. Seminole Tribe v. Florida, 517 U.S. 44, $72-73$ (1996). Some have also suggested that the legal sources for tribal and state sovereign immunity differ. See, e.g., Theresa R. Wilson, Nations Within a Nation: The Evolution of Tribal Immunity, 24 AM. INDIAN L. REV. 99, 101 (2000) ("Unlike state immunity, which is written directly into the Constitution by the Eleventh Amendment, tribal immunity is a product of case law."). This understanding is far too simplistic. The text of the Eleventh Amendment goes only a small way toward establishing robust sovereign immunity. See Alden v. Maine, 527 U.S. 706, 713 (1999) (" $[T]$ he sovereign immunity of the States neither derives from, nor is limited by, the terms 
immunity can be abrogated under Congress's plenary authority. ${ }^{186}$ Nevertheless, the point remains that until Congress acts, both tribes and states retain this important component of their sovereignty - a right that was not given to them by anyone but retained by virtue of their status as sovereigns.

What's more, both tribes and states may proceed parens patriae in litigation. ${ }^{187}$ Parens patriae suits have the advantage of allowing the sovereign to sue on behalf of a widely shared injury suffered by its population where no one individual has standing to bring the suit. ${ }^{188}$ But because " $[t]$ he parens patriae action has its roots in the common-law concept of the "royal prerogative" of the sovereign to care for its citizenry, this type of lawsuit is necessarily reserved to sovereign entities alone ${ }^{189}$ Consequently, not just anyone can file a parens patriae suit: the privilege of doing so has been denied to cities $^{190}$ and foreign nations, ${ }^{191}$ because neither cities nor foreign nations are sovereigns within the federal system. This poses no obstacle for tribes to assert quasi-sovereign interests in the federal courts.

The existence of the parens patriae suit is hardly an irrelevant consideration. Although not directly employed by Massachusetts, the Massachusetts Court relied heavily on the parens patriae doctrine in its articulation of standing rules. The parens patriae and special solicitude doctrines are motivated, at least in part, by the same consideration: the quasi-sovereign interest of the sovereign in the well-being of its population. The state's right to proceed parens patriae gave the Court reason to give states the benefit of "special solicitude." This same reasoning applies with equal force to tribes.

of the Eleventh Amendment. Rather,. . . the States' immunity from suit is a fundamental aspect of the sovereignty which the States enjoyed before the ratification of the Constitution, and which they retain today ..."). Both tribes and states enjoy sovereign immunity based on their status as pre-Constitutional sovereigns.

186. Santa Clara Pueblo, 436 U.S. at 56-58.

187. E.g., Standing Rock Sioux Indian Tribe v. Dorgan, 505 F.2d 1135, 1137 (8th Cir. 1974). See generally Allan Kanner, Ryan Casey, \& Barrett Ristroph, New Opportunities for Native American Tribes to Pursue Environmental and Natural Resource Claims, 14 DUKE ENVTL. L. \& POL'Y F. 155 (2003); Note, Native Americans: The Tribe as Parens Patriae, 5 Mich. J. RACE \& L. 665 (2000).

188. Comment, State Standing to Challenge Federal Administrative Action: A ReExamination of the Parens Patriae Doctrine, 125 U. PA. L. REV. 1069, 1074-78 (1977). (1982).

189. Alfred L. Snapp \& Son, Inc. v. Puerto Rico ex rel. Barez, 458 U.S. 592, 600

190. City of Sausalito v. O'Neill, 386 F.3d 1186, 1197 (9th Cir. 2004).

191. Estados Unidos Mexicanos v. DeCoster, 229 F.3d 332 (1st Cir. 2000). 
Our argument for equality of tribes and states in the standing analysis is even stronger when it comes to environmental litigation because the federal government frequently treats states and tribes alike when it comes to the development of environmental policy. ${ }^{192}$ EPA, the "first federal agency to formally adopt an Indian policy," has long recognized the responsibility of tribes in the field of environmental regulation. ${ }^{193}$ The policy.emphasized tribal selfgovernment, and noted that "Tribal Governments [are] sovereign entities with primary authority and responsibility for the reservation populace."194 As a result, the policy called for the agency to assume a "government-to-government" relationship with tribes, and to delegate environmental regulation to Indian tribes "under terms similar to those governing delegations to States."

Congress codified and expanded this practice by writing it into major environmental statutes, such as the Clean Water Act and the Clean Air Act. ${ }^{196}$ These complex environmental statutes provide a considerable role for both classes of subordinate sovereigns to regulate. Implicitly, these laws recognize the importance of states and tribes in creating effective environmental policy, and the interest that each possesses in a healthy environment.

Through the 1987 Amendments to the Clean Water Act, Congress directed that "Indian tribes shall be treated as States" ${ }^{197}$ under certain circumstances for purposes of administering that law. This gives tribes the same authority as states to assume the permitting process for discharges into navigable waters from "point sources" such as pipes and ditches. ${ }^{198}$ Yet this power is not absolute, and both tribes and states find themselves relying on the federal government in important ways.

The Clean Air Act-the basis for the petitioners' complaint in

192. See generally David F. Coursen, EPA's New Tribal Strategy, 38 ENVTL. L. REP. NEwS \& ANALYSIS 10643, 10643 (2008).

193. Id.

194. EPA, POLICY FOR THE ADMINISTRATION OF ENVIRONMENTAL PROGRAMS ON INDIAN RESERVATIONS (1984), http://www.epa.gov/tribalportal/pdf/indian-policy-84.pdf.

195. Id. at 2.

196. 33 U.S.C. $\$ 1377$ (a) (Westlaw 2009); 42 U.S.C. $\$ 7601$ (d) (Westlaw 2009). Significantly, under these statutes, Congress has delegated to tribes authority to regulate that had been eroded by recent Supreme Court decisions. See, e.g., Ariz. Pub. Serv. Co. v. EPA, 211 F.3d 1280 (D.C. Cir. 2000). See generally Thomas P. Schlosser, Federal Delegation of Tribal Jurisdiction Over Nonmembers (Sept. 1999), http://www.msaj.com/papers/feddeleg.htm..

197. 33 U.S.C. $\$ 1377$ (a) (Westlaw 2009).

198. 33 U.S.C. $\$ 1362$ (12)(A) (Westlaw 2009). 
Massachusetts-also treats tribes as states. The Clean Air Act authorizes states to assume responsibility for developing plans (known as State Implementation Plans, or SIPs) to achieve established ambient air quality standards. ${ }^{199}$ In 1990, Congress amended the Clean Air Act to authorize EPA to "treat Indian tribes as States" if they satisfy certain criteria. ${ }^{200}$ This extended to "Indian tribes the same opportunity as states to implement" plans under the SIP program. ${ }^{201}$ The difficulty in implementing a successful SIP program has been emphasized by one commentator as the real motivation for Massachusetts's lawsuit. ${ }^{202}$ Tribes, like states, have been largely precluded from directly regulating automobile emissions, and therefore, like states, have an interest in seeing EPA pick up the slack.

Even in areas with clean air, both tribes and states may seek to re-designate their territory into a more protective category to improve air quality - a right that has been exercised by Indian tribes on six occasions, and by states on none. ${ }^{203}$ Outside their legal duties, tribes are assuming a role equal to (and in some cases greater than) that of states in reaching voluntary compacts to reduce greenhouse gas emissions. ${ }^{204}$ This similar treatment makes the argument for tribal "special solicitude" the strongest in cases where the tribe seeks to redress an environmental harm.

The final point to make about tribal versus state sovereigntythe source of that sovereignty-may be the most fundamental. State claims to sovereignty are rooted in the Constitution; tribal claims are pre-constitutional, even extra-constitutional. There is a definite contrast here, but it is not clear what the upshot is. The "Supreme Law of the Land" recognizes state sovereignty, ${ }^{205}$ but "it

199. 42 U.S.C. $\$ \$ 4707$ (a), 4710 (Westlaw 2009).

200. 42 U.S.C. $\$ 7601$ (d) (Westlaw 2009). See generally Mark E. Chandler, A Link Between Water Quality and Water Rights?: Native American Control over Water Quality, 30 TULSA L.J. 105 (1994).

201. Michigan v. EPA, 268 F.3d 1075, 1078 (D.C. Cir. 2001).

202. Morriss, supra note 43, at 209-11.

203. Sarah B. Van de Wetering \& Matthew McKinney, The Role of Mandatory Dispute Resolution in Federal Environmental Law: Lessons From the Clean Air Act, 21 J. ENVTL. L. \& LITIG. 1, 3-4 (2006).

204. The Climate Registry, a coalition of United States and Mexican states, Canadian provinces, and Indian tribes, is an example of one such agreement. See Climate Registry Brochure, http://www.theclimateregistry.org/downloads/Registry_Brochure.pdf (last visited Nov. 29, 2009).

205. See U.S. CONST. amend. X ("The powers not delegated to the United States by the Constitution, nor prohibited by it to the States, are reserved to the States respectively, 
is at least arguable that the origin of tribal sovereignty is more consistent with some philosophical notions of a 'sovereign' than the already-compromised sovereignty of states that emerges from the Constitution." ${ }^{206}$ That is, states have to admit that they voluntarily gave up some aspect of their sovereignty when they ratified the Constitution; tribes need make no such admission. ${ }^{207}$ Tribes may need to concede that they were stripped of some of their sovereignty against their will, but this is different from ceding sovereignty voluntarily (or contractually) as did states. This is one more way, perhaps, in which tribal claims to sovereignty are stronger than those of the states. Neither are full-fledged sovereigns as it now stands, but the road they took to arrive at that point should not be ignored.

\section{B. Equal Standing With States}

So where are we going with all this? It's quite simple, really. Massachusetts $v$. EPA says sovereigns get "special solicitude" in the standing analysis; tribes (like states) are sovereign; therefore courts should treat tribes like states when making the standing inquiry. And, we would add, tribes' need for special solicitude is greater than that of states.

Special solicitude for tribes follows logically from Massachusetts v. EPA. To the extent that tribal sovereignty has been recognized by the courts, it is subject to divestment by Congress at will. As argued above, the special solicitude rule is driven in no small part by preemption: the loss of rulemaking authority due to the actions of a higher sovereign. Both states and tribes can suffer . preemption, but Congress has plenary authority to act in tribal matters, thereby exposing tribes to the risk of virtually unlimited preemption. With this limitation in regulatory power comes a commensurate need to invoke the judiciary's aid in compelling federal action for the benefit of the tribe's citizenry.

The constitutional source for the bulk of Congress's power to

or to the people."); Nat'l League of Cities v. Usery, 426 U.S. 833, 842-43 (1976), overruled by Garcia v. San Antonio Metro. Transit Auth., 469 U.S. 528 (1985) ("While the Tenth Amendment has been characterized as a truism . . . it is not without significance. The Amendment expressly declares the constitutional policy that Congress may not exercise power in a fashion that impairs the States' integrity or their ability to function effectively in a federal system." (internal quotations and citations omitted)).

206. Sarah Krakoff, A Narrative of Sovereignty: Illuminating the Paradox of the Domestic Dependent Nation, 83 OR. L. REV. 1109, 1156 (2004).

207. Id. 
regulate in non-Indian affairs is the Commerce Clause, coupled with the Necessary and Proper Clause. ${ }^{208}$ Between the 1940s and 1990s, the Supreme Court upheld every law passed by Congress pursuant to its Commerce Clause authority. However, it never conceded that Congress in fact possessed plenary authority to regulate. Instead, the Court formally scrutinized every statute.

As mentioned above, there is no such limit when it comes to regulation of tribes and preemption of tribal laws. The Supreme Court has recognized that Congress possesses general police power to regulate affairs in Indian country. ${ }^{209}$ This authority has remained absolute during eras of both broad and narrow conceptions of the Commerce Clause vis-à-vis states. For over one hundred years, the Supreme Court has recognized congressional authority to pass general criminal laws governing Indian country. ${ }^{210}$ In contrast, even at the height of congressional power over states, the Supreme Court stressed that Congress may not pass general criminal laws without establishing a connection to interstate commerce. ${ }^{211}$ And

208. Reeve T. Bull, Note, The Virtue of Vagueness: A Defense of South Dakota v. Dole, 56 DUKE L.J. 279, 281 (2006).

209. E.g., United States v. Lara, 541 U.S. 193, 200 (2004) (“[T]he Constitution grants Congress broad general powers to legislate in respect to Indian tribes, powers that we have consistently described as "plenary and exclusive."'); Cotton Petroleum Corp. v. New Mexico, 490 U.S. 163, 192 (1989) (finding that the Indian Commerce Clause vests "Congress with plenary power to legislate in the field of Indian affairs"). This rule has been heavily criticized, as it is strange that the same Constitutional provision, the Commerce Clause, with the same language could carry such dramatically different interpretations depending on the subject of the regulation. See Fletcher, Federal Power, supra note 169, at 522 ("The text of the Indian Commerce Clause suggests (perhaps) that congressional authority in the field of Indian affairs is less than plenary, if one accepts the argument that "commerce" does not include the entire field ...."); id. at 565 (observing that scholarship suggests "this is a weak source of authority"). Justice Thomas has raised questions about the Court's unquestioning acceptance of the plenary-power doctrine:

I do, however, agree that this case raises important constitutional questions that the Court does not begin to answer. The Court utterly fails to find any provision of the Constitution that gives Congress enumerated power to alter tribal sovereignty. The Court cites the Indian Commerce Clause and the treaty power. I cannot agree that the Indian Commerce Clause "provide[s] Congress with plenary power to legislate in the field of Indian affairs." At one time, the implausibility of this assertion at least troubled the Court, and I would be willing to revisit the question.

Lara, 541 U.S. at 224 (2004). (Thomas, J., concurring) (citations omitted) (quoting Cotton Petroleum, 490 U.S. at 192).

210. See, e.g., United States v. Kagama, 118 U.S. $375,378-79$ (1886).

211. See Perez v. United States, 402 U.S. 146, 151-52 (1971). 
while more recent decisions have invigorated at least some judicial limits on Congress's Commerce Clause authority as it relates to states, ${ }^{212}$ the Court has declined to extend this reasoning to the regulation of Indian country. ${ }^{213}$ Because power to regulate involves power to preempt, this means there are many areas in which tribes can lose their rulemaking ability, even more than states. ${ }^{214}$

The broad powers over Indian tribes are intertwined with another aspect of the relationship between the federal government and tribes: the trust relationship. While the federal government owes nothing to states other than compliance with the law, it "owes fiduciary duties to American Indians." 15 Originally founded in racism $^{216}$ and a patronizing view of the tribe as a ward dependent on its guardian, ${ }^{217}$ the actions of the federal government to tribes to this day are understood in light of the existence of a trust relationship. ${ }^{218}$ This relationship has given tribes broader authority than others to sue for violations of a statute or regulation by the United States. While the Supreme Court has insisted that the statute or regulation must establish a fiduciary obligation, it has construed such laws broadly in light of "the undisputed existence of a general trust relationship between the United States and the Indian people," ${ }^{119}$ and authorized monetary damages for breach where the substantive law in question did not. ${ }^{220}$ When an agency fails to regulate when it should, tribes suffer a breach of this trust relationship. Tribal regulation and preemption often come from the bureaucracy rather than the legislature. "A great deal of Congress's authority in Indian Country is delegated to the Bureau of Indian Affairs." ${ }^{221}$ Judicial review of agency action is even more

212. See United States v. Lopez, 514 U.S. 549, 564 (1995) (emphasizing that the general criminal law lies beyond Congress's authority). See also United States v. Morrison, 529 U.S. $598(2000)$.

213. Lara, 541 U.S. at 200.

214. For example, Congress has limited the authority of tribes to enforce criminal legislation over tribal members when the term of imprisonment exceeds one year. 25 U.S.C. § 1302(7) (Westlaw 2009).

215. Reid Peyton Chambers, Judicial Enforcement of the Federal Trust Responsibility to Indians, 27 STAN. L. REV. 1213, 1213 \& n.1 (1975) (collecting cases).

216. See Note, Rethinking the Trust Doctrine in Federal Indian Law, 98 HARV. L. REV. 422, 426-27 (1984).

217. Cherokee Nation v. Georgia, 30 U.S. (5 Pet.) 1, 17 (1831).

218. See United States v. Navajo Nation, 537 U.S. 488, 505-06 (2003).

219. United States v. Mitchell, 463 U.S. 206, 225 (1983).

220. Navajo Nation, 537 U.S. at 506.

221. Jacob T. Levy, Three Perversities of Indian Law, 12 TEx. REv. L. \& POL. 329, 334 
needed for tribes, given the vast amount of power wielded by these agencies over tribal affairs. One would also expect tribes to be better advocates in federal court than their state counterparts. Critical to the Supreme Court's "special solicitude" rule is its belief that state litigation fulfills the goals of standing by providing zealous advocacy. ${ }^{222}$ Yet whether a state will represent its position more fervently than an ordinary litigant or ideologically motivated nonprofit organization is also far from clear. Determining its litigation position-like crafting policy-often requires the state decision maker to take the stance favorable to one faction of the citizenry over another. The position ultimately adopted may be largely due to the beliefs of the person elected as attorney general. ${ }^{223}$ Elections cause changes in personnel and state policy, and coalitions and constituent concerns shift rapidly. ${ }^{224}$ And some state actors might act solely for political reasons, rather than an actual interest in promoting the health or safety of their citizenry. ${ }^{225}$

In contrast, tribes are smaller, more cohesive units with internal cultural homogeneity that exceeds anything approached by states. ${ }^{226}$ The likelihood that a minority will capture the sovereign as a vehicle for vocalizing its concerns is greater in the instance of a state than a tribe. And after a tribe commits its limited resources to a lawsuit, it is unlikely it will simply abandon it.

There are other, perhaps more fundamental reasons why tribes

(2008)

222. See Massachusetts v. EPA, 549 U.S. 497, 521 (2007). The Court was not alone in this conclusion: a leading treatise (recognized by the majority opinion as an authority) concluded that "[s] tate-instituted litigation is likely to satisfy all the functional needs of the adversary process." 13B Charles AlAN WRIGHT, ARTHUR R. MILler, \& EDWARD H. COOPER, FEDERAL PRACTICE AND PROCEDURE $\$ 3531.11 .1$ (3d ed. 2008).

223. Several commentators have noted the increased role that attorneys general may have under the "special solicitude" afforded to states. Mank, Standing, supra note 63, at 1780-85; Dru Stevenson, Special Solicitude for State Standing: Massachusetts v. EPA, 112 PENN ST. L. REV. 1, 37-50 (2007).

224. The fact that the state of Idaho intervened at the Court of Appeals but chose not to join or file a brief in the Supreme Court, effectively abandoning the case prior to its resolution, casts doubt on the Court's confidence in states.

225. One commentator, for example, suggests that Texas's location along the coast and high rate of pollution will create "unwelcome and catastrophic consequences of climate change" within the state. Powers, supra note 88 , at 148-49. However, Texas supported EPA's decision to not regulate greenhouse gases.

226. See Vine Deloria, Jr. \& Clifford M. Lytle, The Nations Within: The Past AND FUTURE OF AMERICAN INDIAN SOVEREIGNTY 18 (1984); Wenona T. Singel, Cultural Sovereignty and Transplanted Law: Tensions in Indigenous Self-Rule, 15 KAN. J.L. \& PUB. POL'Y 357,367 (2006). 
in particular make good environmental plaintiffs: the importance of sovereignty to tribes (they covet it) and a disposition towards environmental stewardship (reflecting a deeper relationship with the land).

For all the limitations of Indian sovereignty discussed above, the special status of tribes in the eyes of the law cannot be overlooked. Nor can we overstate tribes' affinity for their sovereignty. ${ }^{227}$ According to William H. Rodgers, tribal sovereignty is a "precious asset," particularly in the environmental context. ${ }^{228}$ The movement for greater sovereignty has coincided with the movement for better stewardship of the earth, and the two complement each other. The confluence of these movements has yielded new innovations in conservation, such as tribal conservation trust projects. ${ }^{229}$ Apart from federal environmental law, where assertion of tribal sovereignty plays a key role, tribal "natural" law is inextricably intertwined with sovereignty. Many tribes believe, as a matter of religion, that they are appointed as stewards of the world around them. ${ }^{230}$ Sovereignty is crucial: "In effect, tribes use their sovereignty to exercise their spiritual duty to

227. Krakoff, supra note 206, at 1111 . If the Supreme Court were ever to abrogate tribal sovereignty, Professor Krakoff opines that the decision would be

met with shock and outrage by many members of tribal nations for whom "sovereignty" is as common and heartfelt a term as "rights" is to most other Americans. Many tribal members perceive that their cultural survival is inextricably linked to their existence as separate, self-governing nations, and that dealing a final blow to the legal doctrine of sovereignty would be akin to terminating tribal people themselves.

Id.

228. William H. Rodgers, Jr., Tribal Government Roles in Environmental Federalism, 21WTR NAT. RESOURCES \& ENV'T 3, 3 (2007). Rodgers makes the point with a pair of rhetorical questions: "Is sovereignty a valuable asset to have in contemporary environmental struggles? Just ask the Natural Resources Defense Council or the Sierra Club or the National Wildlife Federation. Would they turn down 'sovereignty' were there a chance to seize it?" Id.

229. Mary Christina Wood \& Matthew O'Brien, Tribes as Trustees Again (Part II): Evaluating Four Models of Tribal Participation in the Conservation Trust Movement, 27 STAN. ENVTL. L. J. 477, 505 (2008). On the other hand, some scholars have noted that the environmental movement can pose a threat to tribal sovereignty if its advocates are too narrowly focused on the environment, thereby ignoring tribes' sovereign interests. See, e.g., Eileen Gauna, El Dia de los Muertos: The Death and Rebirth of the Environmental Movement, 38 ENVTL. L. 457, 465-66 (2008).

230. Mary Christine Wood \& Zachary Welker, Tribes as Trustees Again (Part I): The Emerging Tribal Role in the Conservation Trust Movement, 33 HARV. ENVTL. L. REV. 373, 385 (2008). 
protect the interests of beneficiaries in distant generations."231

And Indian tribes have a lot to lose. Tribal land holdings are vast and unique. Ironically, for the original federal policies sought the exact opposite result, ${ }^{232}$ tribes today lay claim to a treasure trove of natural resources and places of extreme beauty. Indians account for less than one percent of the nation's population, yet they own $40 \%$ of this country's coal reserves, $65 \%$ of its uranium reserves, large amounts of gold, silver, cadmium, oil, copper, zinc, and billions of cubic feet of natural gas. ${ }^{233}$ They have vast timber resources, all while "guard[ing] the door to 20 percent of the nation's freshwater and millions of acres of pristine real estate."234 These holdings are threatened in myriad ways, and the outlook is often grim. However, with the tool of sovereignty, tribes have the strength to fight back.

Additionally, Indians may have more reason than most to be offended by environmental crises, for they tend to possess a special relationship with their lands. This is partly due to legal restrictions and partly the product of cultural phenomena.

Legally, tribal members face obstacles that make it much more difficult for them to pick up and move. Land in "Indian Country" - a broad, legally significant term-includes land on reservations, "dependent" Indian communities (such as the New Mexico pueblos), land that the federal government holds in trust for individual tribal members, and land that tribal members hold in fee but with restrictions on alienation. ${ }^{235}$ So while " $[\mathrm{t}]$ ribes and individual Indians own the beneficial interest in $\mathbf{5 5}$ million acres of land," ${ }^{, 36}$ strings are firmly attached to each and every acre. An Indian who lives on a parcel of trust land, for instance, has no power to sell: the United States holds title to the land; the tribal government manages it for the benefit of the tribal community;

231. Id.

232. See Lee Herold Storey, Comment, Leasing Indian Water off the Reservation: A Use Consistent with the Reservation's Purpose, 76 CAL. L. REV. 179, 200-01 (1988) (discussing the purpose and effect of the Indian Removal Act of 1830).

233. Paul Vandevelder, Coyote Warrior: One MaN, Three Tribés, and the TRIAL THAT FORGED A NATION 3 (2004).

234. Id.

235. 18 U.S.C. $\$ 1151$ (Westlaw 2009); see also Kristina L. McCulley, The American Indian Probate Reform Act of 2004: The Death of Fractionation or Individual Native American Property Interests and Tribal Customs?, 30 AM. INDIAN L. REV. 401, $406-07$ (2006).

236. Kevin Gover, Moving Beyond the Current Paradigm: Redefining the Federal-Tribal Trust Relationship for This Century, 46 NAT. ReSOURCES J. 317, 346 (2006). 
and the tribe can sell the land only if the federal government approves. ${ }^{237}$ The result is frustratingly simple: the law makes it burdensome for tribal members to leave.

That said, staying on traditional lands finds support in Indian culture. Historical revisionism has done its part to paint Indians as selfless keepers of the earth. ${ }^{238}$ That picture is not wholly accurate-Indian tribes overused fire as a land-control mechanism, overharvested beaver, buffalo, and perhaps even mastodon ${ }^{239}$-but it is well established that many Indians have traditionally viewed the earth in a way very different from their white American counterparts. They have approached the land with something akin to a Gaia philosophy:

a perception of the earth as an animate being; a belief that humans are in a kinship system with other living things; a perception of the land as essential to the identity of the people; and a concept of reciprocity and balance that extends to relationships among humans, including future generations, and between humans and the natural world. ${ }^{240}$

In Lyng v. Northwest Indian Cemetery Protective Association, 485 U.S. 439 (1988), the Supreme Court took note of the spiritual relationship between a tribe and its land. Although the Court rejected the tribe's challenge to a logging project on free-exerciseof-religion grounds, it credited the tribe's contention that its religion and worldview were anchored deeply in geography:

237. See id. at 347; Denise Chee, Unique Aspects of Housing Development on Tribal Lands, 10-SPG EXPERIENCE 7, 8-9 (2000); Ezra Rosser, This Land Is My Land, This Land Is Your Land: Markets and Institutions for Economic Development on Native American Land, 47 ARIZ. L. REV. 245, 259 (2005); see also Alex Tallchief Skibine, Making Sense Out of Nevada v. Hicks: $A$ Reinterpretation, 14 ST. THOMAS L. REV. 347, 368 (2001). (1999).

238. See generally SHEPARD KRECH III, THE ECOLOGICAL INDIAN: MYTH AND HISTORY

239. See PAGE, supra note 5, at 36-40 (discussing the "Pleistocene Overkill," a controversial theory positing that Native Americans drove mastodons to extinction between 11,500 and 10,800 B.C.).

240. Rebecca Tsosie, Tribal Environmental Policy in an Era of Self-Determination: The Role of Ethics, Economics, and Traditional Ecological Knowledge, 21 VT. L. REV. 225, 276 (1996). Tsosie's thoughts are insightful, but the environmental compassion of Indians is even more evident in the words of Indians themselves. The number of pleas by native leaders over the years for a more sensitive approach in things ecological is remarkable. Chief Seattle's is perhaps the most stirring, underscoring the idea that many Indians traditionally thought of the earth as a living creature. See Chief Seattle's 1854 Oration, http://www.halcyon.com/arborhts/chiefsea.html (last visited Jan. 18, 2010). 
Those [religious] practices are intimately and inextricably bound up with the unique features of the Chimney Rock area, which is known to the Indians as the "high country." Individual practitioners use this area for personal spiritual development; some of their activities are believed to be critically important in advancing the welfare of the Tribe, and indeed, of mankind itself. The Indians use this area, as they have used it for a very long time, to conduct a wide variety of specific rituals that aim to accomplish their religious goals. According to their beliefs, the rituals would not be efficacious if conducted at other sites than the ones traditionally used, and too much disturbance on the area's natural state would clearly render any meaningful continuation of traditional practices impossible. ${ }^{241}$

The bulk of evidence suggests that the tribe in Lyng was anything but an aberration. Part of this is due to the fact that Indians have viewed themselves as tied to certain spaces in perpetuity, a view that has been reinforced by the legal restrictions discussed above. The sacred tribal sites littered across the American West stand as testaments to this way of life. ${ }^{242}$

David Getches has dubbed this worldview a "philosophy of permanence." ${ }^{43}$ This is a mentality that "commits the people to a permanent existence in harmony with everything around them" and "explains the success of these people in surviving in America for thousands of years," from prehistoric challenges to the slings and arrows of life on the reservation. How much this "philosophy of permanence" has eroded with the passage of time is subject to debate, but old habits die hard. ${ }^{244}$ A vivid example of contemporary

241. Lyng v. Nw. Indian Cemetery Protective Assoc'n, 485 U.S. 439, 451 (1988).

242. See generally Kristen A. Carpenter, Old Ground and New Directions at Sacred Sites on the Western Landscape, 83 DEN. L. REV. 981 (2006) (discussing the clash between Indian and non-Indian interests at sacred sites).

243. David $\mathrm{H}$. Getches, A Philosophy of Permanence: The Indians' Legacy for the West, $24 \mathrm{~J}$. W. 54, 54-68 (1990).

244. Getches has argued convincingly that a philosophy of permanence is alive and well in tribal communities. He explains:

The Indians' philosophy of permanence based on an ethical relationship with the land was fully developed at the time of white contact. They survived to that point compatibly with the resources around them by living as if they were there to stay. They have since resisted attempts to change them and to part them from their land and culture against apparently insuperable odds by holding fast to the same philosophical anchor. And they are now sophisticated managers in their own right serving as models for their governments. 
Indians tied to the land comes from the Navajo people of Coyote Canyon, New Mexico. When a child is born in this community, the parents bury the umbilical cord in their land because they expect the child to live and die there. ${ }^{245}$ If that is not symbolic of a philosophy of permanence (and a special relationship with the land), nothing is.

In sum, sovereignty is precious to tribes (they rightfully see it as critical to their very identities) and tribes are uniquely positioned to take care of their natural resources (they tend to hold their land more dearly than most) ${ }^{246}$ Massachusetts $v . E P A$ provides a way for

\section{Id. at 67 .}

245. Hearing on the Health and Environmental Impacts of Uranium Contamination in the Navajo Nation', $11^{\text {th }}$ Cong. (2007) (statement of George Arthur, Chairman, Resources Committee, Navajo Nation Council), http://oversight.house.gov/story.asp?ID=1560. After describing this tradition, Arthur explained that the Navajo are reluctant to move even in the face of extreme contamination from uranium mining: "The Navajos' ties to the land where they are born is profound. We don't just move when conditions become difficult. . . . [R]elocating a Navajo from her ancestral land is tantamount to separating the Navajofrom her spirit." Id. (internal quotation marks omitted).

246. It is also worth noting that international developments are reinvigorating domestic tribal sovereignty. In September 2007, the United Nations issued its Declaration on the Rights of Indigenous Peoples, bolstering native claims for self-governance. The Declaration provides in part:

Indigenous peoples have the right to self-determination. By virtue of that right they freely determine their political status and freely pursue their economic, social and cultural development.

Indigenous peoples, in exercising their right to self-determination, have the right to autonomy or self-government in matters relating to their internal and local affairs, as well as ways and means for financing their autonomous affairs.

Indigenous peoples have the right to maintain and strengthen their distinct political, legal, economic, social and cultural institutions, while retaining their right to participate fully, if they so choose, in the political, economic, social, and cultural life of the State.

...

Indigenous peoples have the right to participate in decision-making in matters which would affect their rights, through representatives chosen by themselves in accordance with their own procedures, as well as to maintain and develop their own indigenous decision-making institutions.

Declaration on the Rights of Indigenous Peoples, G.A. Res. 61/295, Art. III-V, XVIII, U.N. Doc. A/61/L.67 (Sept. 13, 2007),

http://www.un.org/esa/socdev/unpfii/documents/DRIPS_en.pdf (denominations of Articles omitted). Although the Declaration is non-binding (and the United States refused to sign), it has generated momentum internationally and at home. In Bolivia, a country with a majority-indigenous population, President Evo Morales has called for massive reform that would bolster native adjudicatory power. See generally Christopher J. Fromherz, 
tribes to employ their sovereignty in environmental litigation, and the need for special solicitude is greater for tribes than it is for states because tribes are subject to more regulation and their laws are more readily preempted.

\section{CONCLUSION}

There are two classes of sovereigns that exist within the territorial boundaries of the United States but that are distinct from the United States. In 2007, the Supreme Court expanded the ability of states to litigate in federal courts through the articulation of the "special solicitude" doctrine. The rationales motivating this standing rule fully support its application to the other set of sovereigns within the United States-Indian tribes. In fact; the rationales suggest that tribes require the aid of the federal judiciary more than their state counterparts, and will be better advocates for causes that benefit their constituencies. It follows that tribes are entitled to take advantage of the "special solicitude" standing rule announced by the Massachusetts Court.

Professor Felix Cohen famously posited that society's treatment of Indians was analogous to a canary in a coal mine:

Like the miner's canary, the Indian marks the shifts from fresh air to poison gas in our political atmosphere; and our treatment of Indians, even more than our treatment of other minorities, reflects the rise and fall in our democratic faith. ${ }^{247}$

Indian tribes also may provide early warning of environmental harm. Many tribes have unique ties to land and a more direct

Indigenous Peoples' Courts: Egalitarian Juridical Pluralism, Self-Determination, and the United Nations Declaration on the Rights of Indigenous Peoples, 156 U. PA. L. REV. 1341 (2008). In the U.S., a group of Lakota Indians, led by famed Indian activist Russell Means, issued a letter to the Department of State following the Declaration announcing their withdrawal from all treaties with the federal government. Bill Harlan, Lakota Group Secedes from U.S., RAPID CITYJ., Dec. 19, 2007. According to Means, founder of the American Indian Movement, the Lakota are now a sovereign people, "a free country and independent of the United States of America." Id. However, Means does not represent any federally-recognized tribe, and his proposal has received mixed response from elected tribal officials. Bill Harlan, Two Tribal Leaders Reject Secession, RAPID CITY J., Jan. 7, 2008. For now, then, Means's efforts are more symbolic than anything else.

247. Felix S. Cohen, The Erosion of Indian Rights: 1950-1953, A Case Study in Bureaucracy, 62 YALE L.J. 348, 390 (1953). 
relationship with nature. As a result, they may be more sensitive to subtle degradations of the environment that are missed by society at large. These environmental changes will often be too subtle for pre-Massachusetts standing doctrine. Armed with "special solicitude," however, Indian tribes can sound the alarm of impending environmental doom by going to court and requiring adherence to the law by the United States. 


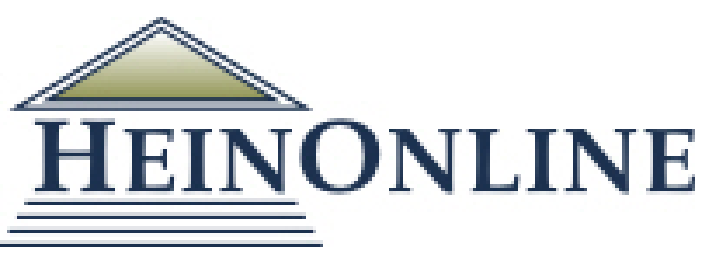

Content downloaded/printed from

HeinOnline

Fri Dec 13 14:14:00 2019

Citations:

Bluebook 20th ed.

Nicholas A. Fromherz \& Joseph W. Mead, Equal Standing with States: Tribal Sovereignty and Standing after Massachusetts v. EPA, 29 Stan. Envtl. L. J. 130 (2010).

ALWD 6th ed.

Nicholas A. Fromherz \& Joseph W. Mead, Equal Standing with States: Tribal Sovereignty and Standing after Massachusetts v. EPA, 29 Stan. Envtl. L. J. 130 (2010).

APA 6th ed.

Fromherz, N. A.; Mead, J. W. (2010). Equal standing with states: Tribal sovereignty and standing after massachusetts v. epa. Stanford Environmental Law Journal, 29(1), 130-180.

Chicago 7th ed.

Nicholas A. Fromherz; Joseph W. Mead, "Equal Standing with States: Tribal Sovereignty and Standing after Massachusetts v. EPA," Stanford Environmental Law Journal 29, no. 1 (2010): 130-180

McGill Guide 9th ed.

Nicholas A Fromherz \& Joseph W Mead, "Equal Standing with States: Tribal Sovereignty and Standing after Massachusetts v. EPA" (2010) 29:1 Stan Envti LJ 130.

MLA 8th ed.

Fromherz, Nicholas A., and Joseph W. Mead. "Equal Standing with States: Tribal Sovereignty and Standing after Massachusetts v. EPA." Stanford Environmental Law Journal, vol. 29, no. 1, 2010, p. 130-180. HeinOnline.

OSCOLA 4th ed.

Nicholas A Fromherz and Joseph W Mead, 'Equal Standing with States: Tribal

Sovereignty and Standing after Massachusetts v. EPA' (2010) 29 Stan Envtl L J 130

Provided by:

Cleveland-Marshall College of Law Library

-- Your use of this HeinOnline PDF indicates your acceptance of HeinOnline's Terms and Conditions of the license agreement available at https://heinonline.org/HOL/License

-- The search text of this PDF is generated from uncorrected OCR text.

-- To obtain permission to use this article beyond the scope of your license, please use: Copyright Information

Use QR Code reader to send PDF to your smartphone or tablet device 